\title{
Heavy nickel isotope compositions in rivers and the oceans
}

\section{Journal Article}

\section{Author(s):}

Cameron, Vyllinniskii; Vance, Derek

Publication date:

2014-03-01

Permanent link:

https://doi.org/10.3929/ethz-b-000080377

Rights / license:

Creative Commons Attribution-NonCommercial-NoDerivatives 4.0 International

\section{Originally published in:}

Geochimica et Cosmochimica Acta 128, https://doi.org/10.1016/j.gca.2013.12.007 

Heavy nickel isotope compositions in rivers and the oceans

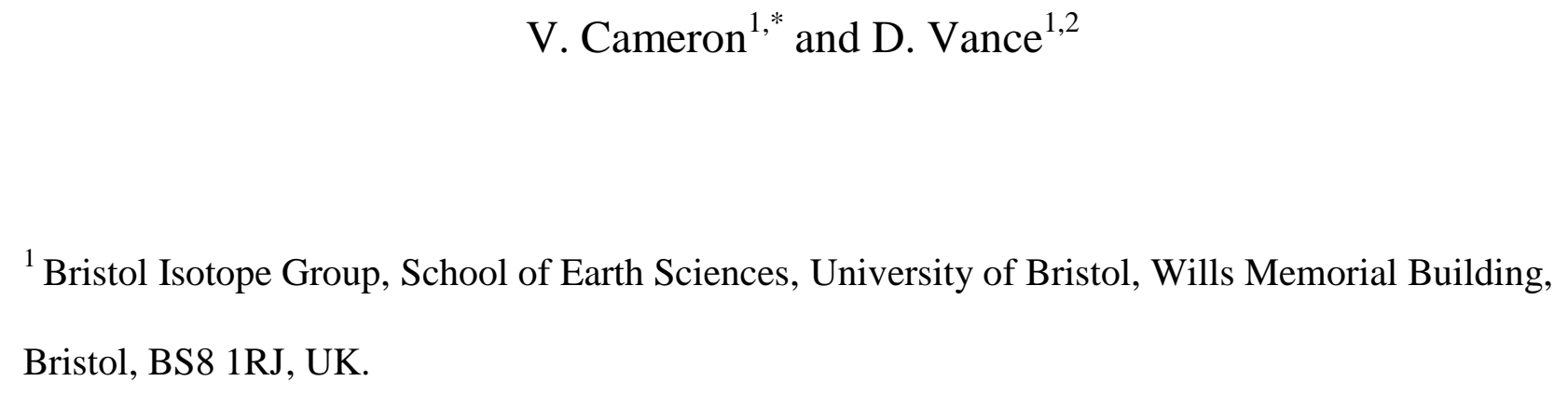

${ }^{1}$ Bristol Isotope Group, School of Earth Sciences, University of Bristol, Wills Memorial Building,

$15{ }^{2}$ Institute of Geochemistry and Petrology, Department of Earth Sciences, ETH Zürich, NW D81.4, 16 Clausiusstrasse 25, Zürich 8092, Switzerland.

17

18 *Corresponding author. e-mail: glxvc@bristol.ac.uk; tel: +44 1173315037; fax +44 1179253385.

19

20

219400 words in main text

229 figures

$23 \quad 2$ tables

24

Keywords: nickel, stable isotopes, rivers, seawater, biogeochemistry, chemical oceanography 26 
Nickel is a biologically-active trace metal whose dissolved concentration depth profiles in the ocean show nutrient-like behaviour. If the pronounced removal of nickel from the dissolved phase in the surface ocean, and its return in the deep, is associated with an isotopic fractionation nickel isotopes may be able to yield constraints on the precise biogeochemical processes involved. Here we present the first nickel isotope data for seawater along with data for the dissolved phase of rivers, one of the principal sources of nickel to the oceans.

The dissolved phase of rivers exhibits substantial variability in both Ni concentration and $\delta^{60} \mathrm{Ni}$ : from 2.2 to $35 \mathrm{nmol} \mathrm{kg}^{-1}$ and +0.29 to $+1.34 \%$, respectively. The most striking result from the nickel isotope analyses of rivers is that they are substantially heavier (by up to $1 \%$ for $\delta^{60} \mathrm{Ni}$ ) than the range for silicate rocks on the continents, a finding that is analogous to that for other transition metal isotope systems. If the data presented here are close to representative of the global riverine flux, they suggest an annual input of $\mathrm{Ni}$ to the oceans of $3.6 \times 10^{8}$ moles, and a discharge- and concentration-weighted $\delta^{60} \mathrm{Ni}$ average of $+0.80 \%$. The relationship between $\mathrm{Ni}$ isotopes and concentrations shows similarities with those for other transition metal isotope systems, where the main control has been suggested to be isotopic partitioning between the dissolved phase and particulates, either in the weathering environment or during transport.

In stark contrast to the rivers, the dataset for seawater is very homogeneous, with 2SD of the entire dataset being only twice the analytical reproducibility. The second main feature is that seawater is distinctly heavier in Ni isotopes than rivers. The average $\delta^{60} \mathrm{Ni}$ is $1.44 \pm 0.15 \%$ (2SD), and only 2 of the 29 seawater analyses have a $\mathrm{Ni}$ isotopic composition that is lighter than the heaviest river. The lack of an isotopic shift associated with the drawdown of nickel concentrations in the surface ocean suggests that the cycling of nickel between the surface and deep ocean is not associated with a pronounced isotopic fractionation. The isotopic data also present a mass balance problem. The main 
51 output of nickel from the oceans (sorption to Fe-Mn oxides) appears to be similar in isotopic 52 composition to the dissolved phase, yet the riverine input is lighter than the dissolved pool. This 53 observation either requires other inputs that are isotopically heavy, or an output that is isotopically 54 light. Further large inputs, over and above the dissolved riverine source, appear to be required by 55 what we know of the elemental budget, but the isotopic mass balance suggests that such an input 56 needs to be isotopically much heavier than both the riverine dissolved load and the lithogenic 57 isotopic composition of nickel. 


\section{INTRODUCTION}

60 Nickel (Ni), like other transition metals, is a biologically-active element (Frausto da Silva and

61 Williams, 2001; Ragsdale, 2009). It has long been known (Sclater et al., 1976; Bruland, 1980) that

62 dissolved Ni concentrations in the modern ocean show a "nutrient-like" distribution with depth.

63 Thus Ni concentrations show depletions in the photic zone that are suggestive of biological uptake.

64 In addition, concentration increases with depth follow the regeneration of major nutrients like

65 phosphate and silica, and the slopes of Ni-phosphate and Ni-silica correlations for dissolved

66 concentrations are similar to those for the $\mathrm{Ni}-\mathrm{Si}_{-} \mathrm{PO}_{4}$ inventories of oceanic phytoplankton (e.g. Lai

67 et al., 2008; Twining et al., 2012). Nickel may have had a more fundamental role in the

68 biogeochemistry of the early Earth (e.g. Williams and Frausto da Silva, 2003; Domagal-Goldman et

69 al., 2008). Methanogens have an absolute requirement for $\mathrm{Ni}$, through the $\mathrm{Ni}$ cofactor in methyl-

70 coenzyme reductase (MCR), which catalyses the terminal step in methanogenesis and may also be

71 involved in methane oxidation (e.g. Thauer, 1998; Kruger et al., 2003; Shima et al., 2012). Methane

72 is a favoured candidate for the dominant greenhouse gas in the anoxic Archean atmosphere (e.g.

73 Kasting, 2005), and it has recently been suggested (Konhauser et al., 2009) that a nickel famine in

74 the late Archean ocean might have precipitated the dramatic rise in atmospheric oxygen that has

75 become known as the Great Oxidation Event (GOE).

76 The isotope systems of the transition metals are increasingly being developed to investigate both the

77 modern oceanic cycling of the transition metals (e.g. Bermin et al., 2006; John et al., 2010;

78 Abouchami et al., 2011; Little et al., 2013; Zhao et al., 2013) and to understand the biogeochemistry

79 of the past Earth (e.g. review by Anbar and Rouxel, 2007). Nickel stable isotopes have been slower

80 to develop than some others. Cameron et al. (2009) presented the first data for terrestrial materials,

81 specifically loess, river sediments and basalts, which had an average $\delta^{60} \mathrm{Ni} \quad(=$

$\left.\left.82\left[\left({ }^{60} \mathrm{Ni} /{ }^{58} \mathrm{Ni}\right)_{\text {sample }} /\left({ }^{60} \mathrm{Ni} /{ }^{58} \mathrm{Ni}\right)_{\text {NISTSRM986 }}\right)-1\right] \mathrm{x} 1000\right)=0.15 \pm 0.12(1 \mathrm{SD}, \mathrm{n}=16)$. These authors also 
83 showed that, in contrast to this homogeneity, methanogens grown in culture take up Ni that is about 1\%o lighter than the culture medium. More recently, Gall et al. (2013) have presented data for hydrogenous $\mathrm{Fe}-\mathrm{Mn}$ crusts which have $\delta^{60} \mathrm{Ni}=0.9-2.5 \%$. Gueguen et al. (2013) reported data for basalts, Mn nodules and organic-rich rocks and suggested a value for the bulk silicate Earth of $+0.05 \%$ while Hofmann et al. (2013) showed enrichment of light $\mathrm{Ni}$ isotopes in magmatic sulphides, with $\delta^{60} \mathrm{Ni}$ at -0.28 to $-0.47 \%$ o $(\mathrm{n}=6)$. A single study (Fujii et al., 2011) has used both a theoretical and experimental approach to suggest that the $\mathrm{Ni}$ isotope compositions of different aqueous species of $\mathrm{Ni}$ could be as great as $2.5 \%$.

Clearly, nickel isotopes are significantly fractionated by Earth surface processes, and thus have some potential in attempts to understand modern and ancient biogeochemical processes. However, there are currently no data for the isotopic composition of dissolved $\mathrm{Ni}$ in the modern oceans. Here we report such data, for samples from the Atlantic, Pacific and Southern Oceans, including three depth profiles that cover all or a substantial portion of the water column. We also report the first data for the dissolved load of rivers, to characterise one of the inputs to the oceans. We use the data to discuss the controls on nickel isotope cycling in the hydrosphere and, with recent data for the principal Fe-Mn oxide output (Gall et al., 2013), to discuss the mass balance of Ni and its isotopes in the modern ocean.

\section{BACKGROUND: OCEANIC BIOGEOCHEMISTRY OF NICKEL}

In the oceanic realm nickel exhibits many biogeochemical features that, qualitatively at least, are common to other transition metals (see review in Bruland and Lohan, 2003). Beginning with the pioneering studies of Sclater et al. (1976) and Bruland (1980), measurements of dissolved nickel distributions have revealed "nutrient-like" profiles. Surveys of the dissolved concentrations of bioactive metals in the oceans have typically found close associations between the depth 
distributions of these metals and individual major nutrients, such as that of $\mathrm{Zn}$ with silicate (e.g. Bruland, 1980; Lohan et al., 2002) and Cd with phosphate (e.g. Boyle et al., 1976; Bruland, 1980; Norisuye et al., 2007). Ni appears to be re-mineralised in close stoichiometry with phosphate in the upper water column, but with silicate (Si) in the deep ocean (Sclater et al. 1976; Bruland 1980). The association with phosphate in the upper ocean implies a sizeable inventory associated with more labile organic matter in phytoplankton. The association with $\mathrm{Si}$ in the deep ocean is common to $\mathrm{Zn}$, and is expressed in the longer lengthscale of remineralisation of $\mathrm{Si}, \mathrm{Ni}$ and $\mathrm{Zn}$ relative to the labile nutrients and $\mathrm{Cd}$. Though this finding also suggests an association with diatom opal, the very low

$115 \mathrm{Zn}$ content of diatom opal itself (e.g. Ellwood and Hunter, 2000; Andersen et al., 2011) means that 116 it cannot be the dominant regenerative source of $\mathrm{Zn}$. Such considerations may also be relevant to 117 Ni. Twining et al. (2012) have shown that cellular Ni in diatoms collected in the field and grown in 118 culture is split approximately equally between frustule and organic material, and that cellular $\mathrm{Ni} / \mathrm{Si}$ 119 ratios are comparable to the slopes of dissolved Ni-Si relationships in the oceans. In the upper water 120 column of the Southern Ocean, Lai et al. (2008) find slopes for dissolved $\mathrm{Ni}^{-\mathrm{PO}_{4}}$ and $\mathrm{Ni}-\mathrm{Si}$ 121 correlations that are both close to stoichiometric ratios for individual plankton cells observed during 122 Southern Ocean fertilization experiments (Twining et al., 2004).

123 There are also some key differences between the oceanic biogeochemistry of Ni and that of other 124 bioactive trace metals. Thus, unlike $\mathrm{Cd}$ and $\mathrm{Zn}$, concentrations of $\mathrm{Ni}$ are never reduced to near zero 125 in the euphotic zone, and in fact never descend beneath about 1.5-2 nM (e.g. Bruland, 1980; Boyle 126 et al., 1981; Bruland and Franks, 1983; Yeats and Campbell, 1983; Morley et al., 1993; Yeats et al., 127 1995; Saager et al., 1997; Mackey et al., 2002; Bowie et al., 2002; Norisuye et al., 2007; Ellwood, 128 2008). Moreover, the increase in concentrations as deep water ages between the Atlantic and 129 Pacific, at factor 1.8, is smaller than for $\mathrm{Zn}$ and $\mathrm{Cd}$, at factor 4-5 (Sclater et al., 1976; Bruland, 130 1980; Bruland and Franks, 1983). Finally, Ellwood (2008) finds little seasonal variation in surface 
131 Ni concentrations in the Subantarctic Zone of the Pacific, despite large changes in $\mathrm{Cd}$ and $\mathrm{Zn}$ 132 correlated with the summer algal bloom and with phosphate depletion.

133 In terms of specific biochemical functions, the identification of nickel-containing metalloenzymes 134 has developed more slowly than for some other metals (see review by Ragsdale, 2009). There have 135 been three biochemical roles identified for Ni that are important in the marine microbial realm, and 136 to its biogeochemical cycling. The importance of Ni in enzymes involved in methane cycling, such 137 as MCR, is well established (e.g. Thauer, 1998; Kruger et al., 2003). Though likely much more 138 widespread on the early Earth (e.g. Kasting, 2005), this metabolism is only relevant to restricted 139 anoxic basins or sediments of the modern ocean, and to life associated with hydrothermal systems 140 (e,g. Kelley et al., 2002). In the modern oxic oceans the most commonly cited role of Ni is in 141 urease, by which phytoplankton hydrolyse urea to yield ammonia (Frausto da Silva and Williams, 142 2001). Thus cultures of diatoms (Price and Morel, 1991) and cyanobacteria (Dupont et al., 2008a) 143 grown on urea as the sole source of nitrogen are limited by $\mathrm{Ni}$, and $\mathrm{Ni}-\mathrm{N}$ co-limitation of 144 phytoplankton is deemed likely in some oceanographic regimes (Price and Morel, 1991). Culturing 145 studies have also found that cyanobacteria are limited by Ni even when grown on nitrate (Dupont et 146 al., 2008a), consistent with the suggestion that these organisms contain a Ni superoxide dismutase, 147 Ni-SOD, an enzyme which catalyses the breakdown of toxic superoxide (Dupont et al., 2008a,b).

148 Concentrations of total dissolved Ni that are never beneath about 1.5-2 $\mathrm{nM}$ in the euphotic zone are 149 not consistent with the suggestion, for example, that $\mathrm{Ni}-\mathrm{N}$ co-limitation may occur in some 150 oceanographic regimes, unless only a small fraction of the dissolved pool is bioavailable (c.f. 151 Mackey et al., 2002). This brings up another feature of Ni's oceanic biogeochemistry that is 152 common to other transition metals. It is commonly assumed that only free metal ions are available 153 for uptake into phytoplankton cells. But for many metals a large proportion of the dissolved pool 154 (operationally-defined as the material passing through a $0.45 \mu \mathrm{m}$ filter) is bound in complexes with 155 organic ligands. It appears that this may be the case for Ni too (van den Berg and Nimmo, 1987; 
Donat et al., 1994; Xue et al., 2001; Turner and Martino, 2006), though estimates of the portion of

157 dissolved Ni that is organically-bound (in complexes with conditional stability constants between 158 $10^{12}$ and $10^{17}$ ) varies from 25 to $99.9 \%$. There is also some debate over the extent to which these 160 opposed to their thermodynamic stability (Gerringa, 1991; Mackey et al., 2002).

161 In terms of whole ocean mass balance, Sclater et al. (1976) suggested a residence time of Ni on the 162 order of $10 \mathrm{kyr}$, with the dissolved load of rivers as the major input. More recently, Gall et al. 163 (2013), on the basis of revised values for the output to pelagic sediments, have calculated a shorter residence time of 4 kyr. It appears that dust and hydrothermal fluids are minor inputs in comparison with some other metals (Sclater et al., 1976; Bruland, 1980; Bowie et al., 2002), while Danielsson et al. (1985) and Bowie et al. (2002) document evidence for a source of $\mathrm{Cu}$ and $\mathrm{Fe}$, but minimal $\mathrm{Ni}$,

167 from sediment. Sclater et al. (1976) also suggested that scavenging by Fe-Mn oxides is the major 168 output. There is no impact on Ni concentrations of the intense oxygen minimum zone of the NW Indian Ocean (e.g. Saager et al., 1992), and Ni concentrations in the deep sulphidic Black Sea are not drawn down by reaction with $\mathrm{H}_{2} \mathrm{~S}$, as they are for many other metals (e.g. Haraldsson and 171 Westerlund, 1988), suggesting that suboxic-anoxic or euxinic sediments may not be as important a 172 sink for Ni as they are for many other metals (e.g. Tribovillard et al., 2006). Ni is actually mildly 173 enriched in euxinic Black Sea sediments relative to upper continental crust, but is much more strongly enriched in non-sulphidic open ocean settings that are characterised by intense upwelling such as the Peru Margin (Boning et al., 2004). This, along with the ubiquity of lowered dissolved Ni concentrations in the photic zone, might suggest that transfer in organic matter is a significant sedimentary sink for Ni (c.f. Tribovillard et al., 2006).

178 The above relatively simple picture may, however, be complicated by a major apparent imbalance 179 in the oceanic Ni budget. Krishnaswami (1976) used measurements of the authigenic output of Ni 180 to pelagic Pacific sediment, as well as the little that was known about the dissolved riverine input at 
181 that time, to suggest that the total output of $\mathrm{Ni}$ is up to six times greater than the dissolved riverine 182 input. We return to this issue in the Discussion section with the additional constraints that derive 183 from the data presented here.

\section{SAMPLES AND METHODS}

\subsection{River samples}

Details of the river samples and their collection can be found in Vance et al. (2008) and Archer and Vance (2008), where data are reported for $\mathrm{Cu}$ and Mo isotopes, respectively, on these samples. In addition, $\mathrm{Zn}$ isotopic data for many of them can be found in Little et al. (2013). All river samples were collected from close to the bank into pre-cleaned, low density polyethylene bottles after prerinsing with the sample 2-3 times. The Amazon, Brahmaputra, Nile and Chang Jiang samples were immediately passed through a pre-cleaned cellulose nitrate $0.2 \mu \mathrm{m}$ filter using a pre-cleaned plastic filter holder and reservoirs, pre-rinsed with filtered sample before final filtrate collection, then decanted into a new pre-cleaned low density polyethylene bottle. The Kalix, Missouri and Tocantins samples were filtered in the same manner up to 2 weeks after collection, on return to the laboratory. All samples were acidified to $\mathrm{pH} 2$ after filtration with concentrated twice-distilled $\mathrm{HCl}$. Samples were pre-concentrated prior to column chromatography and mass spectrometry (see section 3.3) by drying down, treatment with concentrated nitric acid (containing a small amount of

$199 \mathrm{H}_{2} \mathrm{O}_{2}$ ) to oxidise organics, and re-dissolution in a few $\mathrm{ml} \mathrm{HCl}$ before chromatographic separation of 200 Ni (see section 3.3). Following Cameron et al. (2009) mass bias correction for Ni was achieved 201 using a mixed ${ }^{61} \mathrm{Ni}^{6}{ }^{62} \mathrm{Ni}$ double spike (details in section 3.3) and samples were spiked before being dried. Ni concentrations of river samples were first measured by ICPMS to allow accurate spiking 203 (though all concentrations reported here are from the isotope dilution analysis via the double-spike 204 analysis). 


\subsection{Seawater samples}

206 Samples from the Iceland Basin were collected in August 2010 by E.Achterberg (NOCS, UK) on 207 cruise 354 of the RRS Discovery. The cruise was primarily aimed at investigating high-latitude $\mathrm{Fe}$ 208 limitation. The single depth profile measured here for $\mathrm{Ni}$ and its isotopes is from Station 28. 209 Samples were collected using a trace metal clean titanium CTD frame fitted with 10 L trace metal 210 clean Teflon coated OTE (Ocean Technology Equipment) bottles, and were filtered under pressure 211 using $0.2 \mu \mathrm{m}$ pore size cartridge filters (Sartobran P- 300, Sartorius). Samples were acidified to $\mathrm{pH}$ 2121.9 upon return to the Bristol laboratory, and equilibrated with the added acid for weeks before 213 analysis for $\mathrm{Ni}$ isotopes. Water depth at this site was $2229 \mathrm{~m}$, so that the profile presented here 214 covers the entire water column.

215 The single 1000m sample from the sub-tropical North Atlantic site was collected during the June 2162008 US-Geotraces Intercalibration cruise (IC1) aboard $R / V$ Knorr to the Bermuda Atlantic Time 217 Series (BATS) site. The sample was collected with the US GEOTRACES 24-sample 12-L trace 218 element General Oceanics GO-Flo Rosette system deployed on a Kevlar cable. The sample was 219 filtered through $0.2 \mu \mathrm{m}$ Pall Acropak capsule filters in the GEOTRACES clean van, and acidified 220 with $2 \mathrm{~mL}$ distilled $6 \mathrm{~N} \mathrm{HCl}$ per liter of sample. Further details of sampling, as well as data for other 221 trace metal systems, can be found in Boyle et al. (2012). The water depth at this site is approximately $4680 \mathrm{~m}$ so the sample reported here is from well above the bottom.

223 Samples from the Southern Ocean, including 4 surface transect samples and one depth profile through the upper $1500 \mathrm{~m}$ of the water column, were collected during Polarstern cruise ANTXXIV/3 (Feb-April 2008) in the Atlantic sector of the Southern Ocean as part of the International GEOTRACES program and a contribution to the International Polar Year (IPY). Surface samples were collected at $2-5 \mathrm{~m}$ using an IFISH torpedo sampler with an all-Teflon pump. The depth profile was sampled using the TITAN frame (de Baar et al., 2008). Samples were filtered on board in a 
slight nitrogen pressure and collected into acid-cleaned Nalgene high density polyethylene (HDPE)

231 bottles and canisters. Acidification was done onboard to $\mathrm{pH}=2$ with $12 \mathrm{~N} \mathrm{HCl}$ (Baseline, Seastar).

232 The water depth at the depth profile station PS71-104 was 4202m - thus well below the deepest 233 sample reported here for Ni isotopes. These samples have been the subject of studies for both $\mathrm{Cd}$ 234 (Abouchami et al., 2011) and Zn isotopes (Zhao et al., 2013).

235 Samples from the Juan de Fuca Ridge, NE Pacific, were collected in June 2009 by V. Cameron on cruise AT15-47 of the $R / V$ Atlantis. The EAGER (Endeavour-Axial Geochemistry and Ecology Research) Program involved a suite of research activities focussed on several of the hydrothermal vent sites along the Endeavour Segment and at Axial Volcano. Samples for the single depth profile reported here represent off-axis (background) seawater, collected with the Sea-Bird SBE-911plus CTD system fitted with a 23 bottle 10-L Niskin rosette. Filtration was done on board using $0.2 \mu \mathrm{m}$ filter units (Pall VacuCap 60) connected with Teflon tubing, into acid-cleaned Nalgene HDPE bottles. In-line filters were pre-cleaned plastic holders with $0.2 \mu \mathrm{m}$ cellulose nitrate filters. Samples were stored double-bagged in plastic boxes and, immediately on return to Bristol, were acidified to $\mathrm{pH} 2$ with double-distilled $\mathrm{HCl}$. The water depth at this site is no greater than $2400 \mathrm{~m}$.

Samples from the NE Pacific were supplied by M.C. Lohan (University of Plymouth, UK), and were collected either in 1999 or 2001, originally for Zn concentration analysis (Lohan et al., 2002). Samples C1000 and E1000 were collected to investigate trace metal concentrations at the centre and 248 edge of Haida eddies. Sample 26P1000 is from Ocean Station Papa. The three samples were collected by the C.S.S. John Tully with acid-cleaned 30-1 Teflon-coated Go-Flo bottles attached to a Kevlar line and closed with Teflon messengers. The samples were filtered through $0.4-\mu \mathrm{m}$ acid251 cleaned polycarbonate membrane filters and acidified to a $\mathrm{pH}$ of 2 with sub-boiling quartz-distilled $252 \mathrm{HCl}$ on return to the UK. For the decade after collection and until the Ni isotope analyses presented 253 here were performed, the samples had been stored double-bagged in plastic boxes. The water depth 
samples analysed here were collected.

All seawater samples were pre-concentrated by co-precipitation with $\mathrm{Al}(\mathrm{OH})_{3}$, using an approach identical to that used previously for zinc and described in detail in Zhao et al. (2013). Briefly, the acidified sample was spiked (see section 3.3) and doped with an aluminium solution pre-cleaned of nickel. Seawater concentrations were known well enough from previous work to allow appropriate 260 spiking. Following at least 24 hours equilibration, the $\mathrm{pH}$ was raised to $8.5-8.8$ to produce an $261 \mathrm{Al}(\mathrm{OH})_{3}$ precipitate. This precipitate was centrifuged, the supernatant poured off and a volume of MQ adjusted to a similar $\mathrm{pH}$, was added. The mixture was again centrifuged and the supernatant removed; this washing process was repeated once more. The precipitate was finally dissolved in $7 \mathrm{M}$ $\mathrm{HCl}$ and purified for $\mathrm{Ni}$ isotopic analysis as described in section 3.3. The nickel yield from this procedure was $40-90 \%$, as obtained by comparison of the signal size for a spike-free isotope with that of a standard, versus the result for $\mathrm{Ni}$ abundance from isotope dilution. Because the double spike is added before pre-concentration, $100 \%$ yields are not necessary for the accuracy of either $\mathrm{Ni}$ concentrations (by isotope dilution) or isotopic composition (from the double spike reduction). Total analysed amounts of Ni were 110-680 ng, while total procedural blank for the Ni procedure was $11 \mathrm{ng}$, half of which comes from the aluminium solution. Thus, blank corrections to these samples would be $0.02-0.16 \%$, given a likely $\delta^{60} \mathrm{Ni}$ of around $0 \%$. As will be seen later, the dataset presented here is very homogeneous in $\mathrm{Ni}$ isotopes, and there is no correlation at all between $\mathrm{Ni}$ isotopic composition and the amount of $\mathrm{Ni}$ analysed so that these small blank corrections were not applied.

\subsection{Chemical purification and mass spectrometric analysis of nickel}

Separation and purification of nickel was carried out as described in detail in Cameron et al. (2009) with the exception of one additional column step. Briefly, spiked co-precipitated seawater and river samples (see section 3.1) in $7 \mathrm{M} \mathrm{HCl}+\mathrm{H}_{2} \mathrm{O}_{2}$ were loaded onto a first ion-exchange column in which 
taken up in $1 \mathrm{M} \mathrm{HCl} / 1 \mathrm{M}$ ammonium citrate, and the $\mathrm{pH}$ adjusted to 8-9 before loading onto columns

281 filled with Ni resin (Eichrom Technologies). This is a reversal of the column procedure outlined in 282 Cameron et al., (2009) as we discovered that the seawater samples would precipitate (most likely 283 due to the heavy solute load) when adjusted to the high $\mathrm{pH}$ values required for the Ni column. After 284 oxidation to remove Ni-bound DMG, the samples are finally put through a third column, which is a 285 repeat of the first anion column, to clean up any residual Fe and $\mathrm{Zn}$. This last column was deemed necessary as ${ }^{56} \mathrm{Fe}$ after the Ni-resin column was significant. Given the initial anion column, and given the low Fe concentrations in seawater, this post-Ni-column Fe is presumably blank addition. In any case, it was monitored in all samples measured for Ni isotopes, as detailed below.

All isotope analyses were performed at low mass resolution on a ThermoFinnigan Neptune multicollector ICPMS, with samples introduced in $2 \%$ nitric acid via a CPI PFA nebuliser (50 $\mu \mathrm{l} /$ minute) attached to an Aridus desolvating nebuliser system (Cetac, Omaha, NE, USA). Signals were monitored at masses 58, 60, 61, 62 and 64. The latter has a potential ${ }^{64} \mathrm{Zn}$ interference but is not used here. For some types of samples an isobaric interference from residual sample ${ }^{58} \mathrm{Fe}$ is a potential problem at mass 58 . This was dealt with by manual checking of the ${ }^{56} \mathrm{Fe} /{ }^{58} \mathrm{Ni}$ ratio in high resolution prior to the $\mathrm{Ni}$ isotopic analysis and applying a correction to the 58 signal. However, this correction was insignificant, e.g. relative to the propagated internal uncertainty on $\delta^{60} \mathrm{Ni}$, except for two samples. In the case of sample $\mathrm{Kx} 4$ it resulted in an upward correction of $0.38 \%$, and the corrected value is identical to that obtained for sample Kx5. In the case of sample Negro3 it resulted in an upward correction of $0.17 \%$, and the corrected result is identical to sample Negro 2 . The other potentially problematic interference is the ${ }^{40} \mathrm{Ar}^{18} \mathrm{O}$ molecular at mass 58, given that these samples were measured in low resolution. This was reduced to levels of $1-2 \times 10^{-14} \mathrm{~A}$ compared with ${ }^{58} \mathrm{Ni}$ signals in the $10^{-10} \mathrm{~A}$ range for all samples, by the addition of a small amount of $\mathrm{N}_{2}$ to the Aridus sweep gas. The size of the ${ }^{58} \mathrm{Ni}$ molecular, and those of the background signals on all measured Ni masses, was monitored by the measurement of on-peak zeros (aspirating $2 \%$ nitric) prior to each 
sample or standard. The "blank" values obtained were subtracted from sample signals before double-spike reduction.

307 A potential issue with double spike analysis was raised by Bermin et al. (2006) for $\mathrm{Zn}$. The isotopic composition of the double-spike used here is referenced to the following isotope ratios for SRM986: ${ }^{61} \mathrm{Ni} /{ }^{58} \mathrm{Ni}=0.016744,{ }^{60} \mathrm{Ni} /{ }^{58} \mathrm{Ni}=0.385202$ and ${ }^{62} \mathrm{Ni} /{ }^{58} \mathrm{Ni}=0.0533939$. The first of these

310 ratios is assumed. The other two are obtained by mass-bias correction of measured ratios for pure 311 SRM986 obtained during the session in which the spike was calibrated, using an exponential law. 312 Small deviations in the behaviour of the instrument after this session, on any subsequent day when 313 spiked samples and standards are analysed, can arise through, e.g. deviations from the exponential 314 mass bias law used in data reduction or changes in cup efficiencies. These can propagate through to 315 inaccuracies in the $\delta^{60} \mathrm{Ni}$ of the sample. Following Bermin et al. (2006) this is dealt with here using multiple measurements of pure NIST SRM986 during each analytical session to monitor variations in instrument behaviour. The normalised ${ }^{60} \mathrm{Ni} /{ }^{58} \mathrm{Ni}$ and ${ }^{62} \mathrm{Ni} /{ }^{58} \mathrm{Ni}$ ratios obtained are compared to 318 those listed above, and adjustment made to raw isotope ratios of the spike-sample and spike319 standard mixtures to take them into account, before any double-spike reduction is done. The success 320 of this approach is demonstrated by the accuracy and reproducibility of spike-standard mixtures. 321 For the period Aug 2007 until July 2012, mixtures of NIST SRM986 (treated in this case as an unknown) and double-spike with std-spike ratios of 0.1-4 and run during each analytical session gave $\delta^{60} \mathrm{Ni}=0.06 \pm 0.08(\mathrm{n}=184)$. All sample/spike ratios for samples analysed here were between 0.5 and 2.5 .

A further test of accuracy can be obtained by comparison of our nickel isotope data with those obtained independently in other laboratories. There are very few published studies of nickel isotopes, but Gall et al. (2012) recently reproduced two USGS basalt standards for which data were published in Cameron et al. (2009) to $\leq 0.05 \%$. Gall et al. (2013) and Gueguen et al. (2013) also report $\delta^{60} \mathrm{Ni}$ for two Fe-Mn nodule reference materials. They obtain $+1.08 \pm 0.07$ and $+1.03 \pm 0.06$ 
respectively, for Nod A-1 versus values of +1.13 and +1.06 obtained in this laboratory. They also

331 obtain $\delta^{60} \mathrm{Ni}=+0.40 \pm 0.10$ and $+0.36 \pm 0.07$ respectively, for Nod P-1 whereas we have obtained two 332 values at +0.41 .

\section{RESULTS}

\subsection{The nickel concentration and isotopic composition of rivers}

336 All the data obtained here, for rivers and seawater, are shown as a histogram in Fig. 1. The river data are presented in Table 1 and displayed in Fig. 2. The dissolved phase of rivers exhibits substantial variability in both $\mathrm{Ni}$ concentration and $\delta^{60} \mathrm{Ni}$ : from 2.2 to $35 \mathrm{nmol} \mathrm{\textrm {kg } ^ { - 1 }}$ in $\mathrm{Ni}$ concentration and from +0.29 to $+1.34 \%$, respectively.

There are no previous data for nickel isotopes in rivers, but the concentrations reported here can be compared with published data. The lowest Ni concentrations overall are for the Negro, a tributary of the Amazon that drains the lowland regions of the Amazon Basin, and the Kalix, a small river in Arctic Sweden. The range of nickel concentrations found here for the Kalix of 4.1-5.6 nM is within the published range of 2-6 nM (Pekka et al., 2004; Dahlqvist et al., 2007). There are no published nickel data specifically for the Negro, nor for the other major tributary that joins the Negro at Manaus, the Solimoes, but Boyle et al. (1982) document a concentration of 4-5 $\mathrm{nM}$ for the riverine end-member at the mouth of the Amazon. The value reported here for the Tocantins, another major river that debouches into the Atlantic alongside the Amazon at Belem, is $4.5 \mathrm{nM}$. Reported Ni

349 concentrations for the Chang Jiang at its mouth (2-3 nM; Edmonds et al., 1985) are lower than the 6-8 $\mathrm{nM}$ found here at, or upstream of, Wuhan. Measurements up to $400 \mathrm{~km}$ inland of the mouth, however, are closer to those found here, at 4-5nM (Koshikawa et al., 2007), so there may be a real increase upstream. Nickel data have been reported for the Ottawa, and the St. Lawrence system generally (Rondeau et al., 2005). The reported concentrations for the Ottawa show significant inter- 
354 annual variability (6-14 $\mathrm{nM})$ while those at the mouth of the St. Lawrence are temporally constant 355 at 12-13 nM. Both of these are consistent with the value of $12.3 \mathrm{nM}$ reported here. Finally, our 356 concentration for the Missouri at Columbia of $35 \mathrm{nM}$ is just slightly higher than the range 357 previously reported for the Missouri and the Mississippi system generally, at 30-32 nM (Shiller and 358 Boyle, 1987; Shiller, 1997).

359 The most striking result from the nickel isotope analyses is that only two rivers, the Negro and the 360 Brahmaputra, have isotopic compositions that overlap with the range for silicate rocks and

361 sediments reported in Cameron et al. (2009). All other rivers are heavier, with $\delta^{60} \mathrm{Ni}$ up to about $1 \%$ 362 heavier than the "lithogenic" value for the Chang Jiang, a finding that is analogous to that for $\mathrm{Cu}$ 363 (Vance et al., 2008) and Mo (Archer and Vance 2008). In fact, the relationship with Ni 364 concentrations bears some similarity with these other systems and will be returned to in the 365 discussion. Different analyses of the same river, collected at close to the same location but 366 collected, filtered and stored in separate bottles, are all analytically the same (given the long-term 367 reproducibility of standards). There is also very little difference, in either concentration or isotopic 368 composition, between the dry and wet season Nile samples.

\section{$369 \quad 4.2$ Nickel concentrations and isotopic composition in seawater}

370 The data for seawater samples is reported in Table 2 and displayed as depth profiles in Fig. 3-5. 371 Concentrations for these samples range from 3.1 to $11.2 \mathrm{nmol} \mathrm{kg}^{-1}$. The first striking feature of the 372 isotopic data is its homogeneity: the average and 2 standard deviations for the entire dataset is $3731.44 \pm 0.15 \%$, compared to our estimate of the reproducibility based on repeat analyses of standards 374 of $0.08 \%$. The second is that seawater is distinctly heavier in Ni isotopes than rivers. Only 2 of the 37529 seawater analyses have a Ni isotopic composition that is lighter than the heaviest river.

376 As with rivers, there are no published data on nickel isotopes in seawater, but our data for 377 concentrations can be compared with literature values, though this is not always easy because 
locations of previous work are not exactly the same and some of the older concentration datasets have many outliers due to the difficulties with clean sampling and analysis at the time. Despite this, our dataset as a whole for the North Pacific is clearly identical to that of Bruland (1980), with agreement all the way down the depth profiles to a small fraction of a nmol kg-1 (Fig. 6). This is all the more remarkable given that the various stations in Fig. 5 are spread across 35 degrees of latitude and over more than 20 degrees of longitude. Our data for the Iceland Basin in the North Atlantic are similar to those for two nearby stations analysed previously (Yeats and Campbell, 1983; Danielsson et al., 1985), and the same is true for our partial depth profile in the Polar Front Zone of the Southern Ocean (Löscher, 1999), though the latter two datasets are rather noisy compared with the Bruland (1980) North Pacific dataset.

Comparison can also be made between relationships between $\mathrm{Ni}$ concentrations and the major nutrients, for the data presented here and published previously. Fig. 7 shows this relationship for phosphate, with the same datasets from the North Pacific and North Atlantic that feature in Fig. 6 plotted for comparison. It has long been recognised (Sclater et al., 1976; Bruland, 1980) that Ni and phosphate are regenerated in a similar fashion in the upper water column so that concentrations, as expected, are strongly correlated there. Beneath the mid-depth phosphate maximum, however, nickel concentrations continue to increase to a maximum (if present) at much deeper levels, so that deep nickel concentrations are better correlated with silica. This is clearly seen on Fig. 7 for the highest Ni concentrations, which are from depths beneath 1000-1200m, and which lie increasingly off the $\mathrm{Ni}-\mathrm{PO}_{4}$ correlation at greater depth. Nearly all the data presented here, for which we also have phosphate data, are for the upper $1500 \mathrm{~m}$ of the water column, so that the relationship with 399 phosphate (Fig. 7) holds for the entire dataset. The best-fit line yields a slope of $0.0022(\mathrm{~mol} / \mathrm{mol})$, 400 with an $\mathrm{R}^{2}$ of 0.93 . This compares with slopes of $0.0014-0.0027$ for data in the literature (Sclater et 401 al., 1976; Bruland, 1980; Bruland and Fanks, 1983; Yeats and Campbell, 1983; Danielsson et al., 1985; Mackey et al., 2002; Norisuye et al., 2007; Lai et al., 2008). 


\section{DISCUSSION}

\subsection{Controls on the dissolved nickel isotope composition of rivers}

As noted previously, the key feature of the riverine isotopic data is that all but two rivers are distinctly heavier than silicate rocks and sediments. It has also been noted that this same feature has been seen for Mo and $\mathrm{Cu}$ isotopes in rivers (Archer and Vance, 2008; Vance et al., 2008). In these previous studies the possibility that the isotopic compositions of these different metals are

410 lithologically-controlled was discussed and dismissed. For Ni, Gueguen et al. (2013) report $\delta^{60} \mathrm{Ni}$

411 for coal and shale at +0.5 to $+0.6 \%$ and it is possible that variably heavy $\mathrm{Ni}$ isotope compositions in 412 the dissolved phase in rivers can be explained by variable contributions of $\mathrm{Ni}$ from these lithologies. 413 However, for $\mathrm{Mo}$ and $\mathrm{Cu}$, this does not explain the relationship between isotopic compositions and 414 reciprocal concentration, which are much more readily explained in terms of weathering processes. 415 The similarities between the $\mathrm{Cu}$ and $\mathrm{Ni}$ systems are emphasised in Fig. 8, where the Ni isotope data 416 are plotted versus $\delta^{65} \mathrm{Cu}$ where the two are available for the same samples. For most of the data the 417 river samples extend along a positive array to heavy $\mathrm{Ni}$ and $\mathrm{Cu}$ isotopic compositions and away 418 from a value close to the "lithogenic" isotopic composition for both systems. With the exception of 419 the Brahmaputra sample, which has an anomalously light $\mathrm{Ni}$ isotope composition given its $\delta^{65} \mathrm{Cu}$, 420 the $\mathrm{R}^{2}$ for the data in Fig. 8 is 0.75 .

421 The exception already mentioned is the Brahmaputra, but there are no $\mathrm{Cu}$ isotope data for the Negro 422 samples which, like the Brahmaputra, have Ni isotopic compositions close to the lithogenic value. 423 For $\mathrm{Cu}$ there is a general tendency for the isotopic composition to get heavier as riverine $\mathrm{Cu}$ 424 concentrations decrease, and this is also mostly the case for Ni (Fig. 2). But the Brahmaputra is 425 clearly different, and despite the fact that the Negro has the lowest Ni concentration of any river measured here its Ni isotopic composition is close to the value for silicate rocks and sediments (Fig. 
1). There is one clear and well-established characteristic of the Negro that probably explains its behaviour. The River Negro is the archetypal transport-limited river of Stallard and Edmond (1983), who noted its low total cation load (c.f. Ni) and cation ratios close to those of substrate rocks (c.f. Ni isotopes). Of all the Amazonian rivers, the Negro drains the most intensely-weathered terrain. Thus it seems likely that the Negro represents an end-member river composition that is close to isotopic equilibrium with its source rocks, in a terrain that is so intensely-weathered on a timeintegrated basis that the modern supply rate of many cations, including $\mathrm{Ni}$, is slow. It is not clear whether this explanation could apply to the other exception, the Brahmaputra, as well.

In this view, the remaining $\mathrm{Cu}-\mathrm{Ni}$ isotope data would be explained in terms of variations in weathering intensity in terrains that, unlike the Negro, have not experienced intense time-integrated weathering, and thus have not lost a lot of their nickel. Thus, the data for both isotopic systems are consistent with decreasing modern weathering intensity along the array, providing opportunity for 439 isotopic compositions in the dissolved phase of rivers that are increasingly out of isotopic 440 equilibrium with the rocks they drain. We note that this explanation is similar to that advanced for 441 Mo isotopes and concentrations in Archer and Vance (2008), but is different from that put forward 442 for $\mathrm{Cu}$ in Vance et al. (2008). In the latter study, particulate analyses were also available for one 443 river, and this particulate load contained the isotopically light counterpart of the dissolved $\mathrm{Cu}$ load. 444 It was suggested that the $\mathrm{Cu}$ isotope data could be explained by equilibrium partitioning, during 445 transport, of $\mathrm{Cu}$ isotopes between a heavy dissolved load that was predominantly bound to organic 446 ligands and a light particulate load. In the absence of data for the particulate load of Ni in rivers, 447 this is also a tenable explanation for the Ni data, though the explanation in terms of weathering has 448 the advantage that it has an obvious rationale for the Negro data too. On the other hand, another 449 characteristic of the Negro is its high load of dissolved organic (humic) material (Stallard and 450 Edmond, 1983), perhaps allowing the organic complexation of all of its small load of Ni and little 451 partitioning into the solid phase. 
This discussion is of general importance to the characteristics of transition metal isotope systems in rivers, but its resolution must await further, more detailed, studies of river systems.

\subsection{The dissolved riverine input of nickel and its isotopes to the oceans}

Overall, if the data presented here are close to representative of the global riverine flux, the $\mathrm{Ni}$ concentration data combined with the water discharges suggest an annual flux of Ni to the oceans of 3.6 $\times 10^{8}$ moles. This is very close to the estimate of $3.2 \times 10^{8}$ moles $\mathrm{yr}^{-1}$ made by Sclater et al. (1976), though both are below the Gaillardet et al. (2003) estimate of $5.2 \times 10^{8}$ moles $\mathrm{yr}^{-1}$. However, the latter was based solely on an early measurement of the Amazon, whereas roughly half of the $\mathrm{Ni}$ discharge we have measured is also from the Amazon, so this estimate could change with the addition of further data. Boyle et al. (1992) and Edmond et al. (1985) show that the mixing of freshwater and seawater in the Amazon plume and the Chang Jiang estuary are both close to conservative for nickel, so that, at least based on these estuaries, this estimate is not likely to be significantly modified by estuarine processes. In terms of isotopes, the discharge- and concentration-weighted average $\delta^{60} \mathrm{Ni}$ for this group of rivers is $+0.80 \%$, about $0.6-0.7 \%$ o heavier than the "lithogenic" value.

An initial question that is relevant to our overall aim to use these data as an estimate of the input of

$\mathrm{Ni}$ and its isotopes to the oceans, is whether this flux and its isotopic composition is representative of the long-term global flux, particularly in the light of potential anthropogenic perturbation. This question is very difficult to address unequivocally. Generally speaking there does not seem to be a strong correspondence between high Ni concentrations and polluted river systems. For example, the 472 Solimoes and Negro at Manaus, relatively undisturbed rivers, have Ni concentrations that bracket 473 those of the Tocantins at Belem, likely more polluted. This range for the two Amazon tributaries 474 also encompasses the measured concentrations in the Chang Jiang and Brahmaputra, and these are 475 all similar to the likely pristine Kalix (e.g. Pekka et al., 2004). The Nile and Ottawa concentrations are higher at 12-13 nM, but again the Nile in Sudan, where these samples were collected, is likely to 
be relatively undisturbed. The Missouri clearly stands out as having a high Ni concentration, but we note that concentrations down the length of the Mississippi system do not vary dramatically (20-35 nM; Shiller and Boyle, 1987; Shiller, 1997) so that it is possible that this is also close to the river's natural $\mathrm{Ni}$ concentration. It is also the case that $\mathrm{Ni}$ concentrations in rivers have not increased greatly through the $20^{\text {th }}$ century - unlike e.g. $\mathrm{Pb}, \mathrm{Zn}, \mathrm{Cd}, \mathrm{Hg}$ and some others. For example, concentrations in sediments from the Rhine and UK lakes increased by less than factor 2 from 1900 to 1980 , while concentrations in reservoirs along the Neckar have actually decreased (Foster and Charlesworth, 1996).

\subsection{The homogeneity of dissolved Ni isotopes in the oceans}

There are two significant aspects of the isotopic data for seawater: first its homogeneity at $\delta^{60} \mathrm{Ni}=$ $+1.44 \pm 0.15 \%$ (average and 2 standard deviations), and second the fact that this average is $0.6-0.7 \%$ o heavier than the riverine input estimated in section 5.2. In fact, only 3 out of the 29 seawater

samples measured have $\delta^{60} \mathrm{Ni}$ lighter than the heaviest river measured. This section discusses the implications of the first of these first-order observations for cycling of Ni within the oceans, while the next section deals with the implications of the second for whole ocean elemental and isotopic mass balance of $\mathrm{Ni}$

Given the putative roles of Ni in phytoplankton, the ubiquitous depletion of Ni in the surface ocean, and the possibility that phytoplankton uptake involves a kinetic isotopic fractionation, it is perhaps surprising that surface waters in this small preliminary dataset show little significant isotopic shift relative to the deep ocean. There is the slightest hint of anti-correlation between $\mathrm{Ni}$ concentrations and isotopic compositions near the surface of the depth profiles for the Iceland Basin and the Southern Ocean (Fig. 3,5), and it is possible that analytical improvements in the future might turn up analytically resolvable variations in near-surface dissolved $\mathrm{Ni}$ isotopes that would be consistent with significant removal of light isotopes into particulate organic material. The maximum isotopic 501 difference between surface water and local deep water for the above sites, at the limits of the 
uncertainties on the isotope data, is $0.2-0.3 \%$. Because of the modest $(\sim 20-25 \%)$ surface depletions in Ni relative to the local deep ocean, this would actually allow a substantial isotope fractionation associated with $\mathrm{Ni}$ removal, of as much as $0.8-1 \%$. The presence or absence of such a Ni isotopic fractionation associated with phytoplankton uptake could be more easily revealed either by culturing experiments or through paired measurements of filtered seawater and associated 507 particulate organic matter.

508 On the other hand, the NE Pacific (Fig. 4) shows the biggest surface depletion in Ni isotopes relative to the local deep ocean, with no hint at all of heavy surface isotopes. However, the North Pacific is very stratified near the surface, and it is very possible that the topmost measurement here 511 (at 100m) misses any isotopically heavy Ni associated with photic zone uptake of light Ni. For 512 example, recent $\mathrm{Zn}$ isotopic data for depth profiles from the NE Pacific (Vance et al., 2012) reveal 513 that the heavy isotopic residue in the dissolved phase as a result of biological metal uptake is 514 restricted to the top $50 \mathrm{~m}$ of the water column, while at $100 \mathrm{~m}$ a light isotopic composition associated 515 with shallow regeneration is observed.

516 The relative lack of an obvious isotopic imprint associated with the depth cycling of $\mathrm{Ni}$ is further 517 emphasised in Fig. 9, where the Ni isotope data presented here are plotted versus phosphate and 518 silica concentrations. It is striking that, despite the strong correlations between phosphate and $\mathrm{Ni}$ 519 concentrations illustrated in Fig. 7, there is no significant relationship between phosphate and Ni 520 isotopes. In the silica plot, there are again the slightest hints of heavier isotopes associated with the 521 very lowest silica concentrations, but the isotopic values for these low silica samples are the same, 522 within uncertainty, of the deeper samples. Clearly, at least for this preliminary dataset, the 523 biogeochemical cycling of $\mathrm{Ni}$ between the surface and deep ocean is not associated with an isotopic 524 fractionation that is large enough to lead to significantly heavy values associated with the co525 removal of $\mathrm{Ni}$ and the major nutrients in the surface ocean. This conclusion is similar to that arrived 526 at for zinc isotopes by Zhao et al. (2013), an element for which culturing and lake studies (John et 
al., 2007; Peel et al., 2009) point to a significant isotopic effect associated with intra-cellular uptake. Zhao et al. (2013) suggest that the lack of relationships between $\mathrm{Zn}$ isotopes and the major nutrients, despite strong correlations between the latter and $\mathrm{Zn}$ concentrations, indicates that $\mathrm{Zn}$ uptake in the surface ocean, and its marine biogeochemical cycling generally, is dominated by 531 incorporation into the opal frustule of diatoms and its associated extra-cellular organic matter (c.f. 532 Twining et al., 2012). It may be that the same is true for nickel isotopes.

533 In the entire dataset, the only sample that has an analytically resolvable difference in Ni isotopes 534 relative to samples above and below it in the water column is that from $1800 \mathrm{~m}$ in the suite of Juan 535 de Fuca Ridge samples of the NE Pacific profile (Table 2; Fig.4). This sample is $\sim 0.2 \%$ lighter, 536 and it also has around $1 \mathrm{nmol} \mathrm{kg}^{-1}$ more $\mathrm{Ni}$, than those on either side. Long-lived, deep scattering 537 layers associated with a neutrally-buoyant plume, and identified by acoustic anomalies, have been 538 documented for the Juan de Fuca Ridge, in the on-axis vicinity of the $1800 \mathrm{~m}$ depth, off-axis sample 539 (Lupton et al., 1985; Thomson et al., 1992; Burd \& Thomson, 1994). These and other studies (e.g. 540 Cowen et al., 2001) also report the presence of a significant concentration of planktonic and 541 microbial biomass associated with the scattering layer that take advantage of the chemical and 542 nutrient gradients imparted by the plume. It is not certain whether the close proximity of the plume 543 with its attendant suite of abiotic and biotic processes can account for the lighter $\delta^{60} \mathrm{Ni}$ and 544 increased concentration, but we note that similar data has been reported for dissolved Fe associated 545 with hydrothermal plumes (Bennett et al., 2008; 2009; Sharma et al., 2001). Two possibilities that 546 could account for the anomalous datum: (1) given the current lack of data for estimates of 547 hydrothermal impact on oceanic Ni budgets in general, this single sample may represent a local 548 feature attributable to the vent/plume (and we note that different vents may be geochemically 549 distinct in regards to $\mathrm{Ni}$ ); (2) alternatively, there could have been some sort of contamination during 550 sampling or analysis. Both prospects would suggest that the seawater Ni budgets would not be 
significantly affected by hydrothermal inputs. Clearly, this single anomaly has to be duplicated in the future.

\subsection{The elemental and isotopic budget of $\mathrm{Ni}$ in the oceans: budget imbalances and heavy $\mathrm{Ni}$}

\section{isotopes}

The lack of $\mathrm{Ni}$ isotope variation in the deep ocean, as opposed to the absence of variability in the surface ocean associated with biological uptake, is primarily a function of the residence time of $\mathrm{Ni}$ relative to the oceanic mixing timescale. Sclater et al. is (1976) calculate a residence time of around $40 \mathrm{kyr}$ assuming that the dissolved load of rivers is the dominant input. The residence time calculated from the riverine input flux obtained here and an average oceanic concentration of $8 \mathrm{nM}$ (Bruland and Lohan, 2003) is around $30 \mathrm{kyr}$. Thus, given an oceanic mixing timescale of the order of $1 \mathrm{kyr}$ (e.g. Jenkins, 2003) the homogeneity of deep ocean dissolved Ni isotopic compositions is no surprise. However, as discussed below (and c.f. Krishnaswami 1976; Sclater et al., 1976), there is a problem with balance in the oceanic Ni budget that is of wider significance than just the isotopic data.

Fe-Mn crusts are very enriched in Ni (e.g. Gall et al., 2013; up to 0.8 wt. \%) and scavenging to FeMn oxyhydroxides in the water column, with subsequent burial of these oxides in sediments, has 567 previously been identified as the most important output from the oceans (Krishnaswami, 1976; 568 Sclater et al., 1976). Krishnaswami (1976) noted that authigenic Ni associated with these phases in 569 Pacific pelagic sediments outweighed the dissolved riverine input by up to a factor of 6 . This 570 imbalance is also implicit in the fact that Sclater et al. (1976) calculate an output-based residence 571 time for $\mathrm{Ni}$ in the oceans of 6-9 kyr, versus the estimate of 30-40 kyr they and we obtain based on 572 the suggestion that the dissolved riverine load is the dominant input. Both Krishnaswami (1976) and 573 Sclater et al. (1976) only had measurements of two rivers available, one of which was the Amazon. 574 Though the riverine dataset here includes more rivers, it is still dominated by the Amazon. While it is possible that the estimate of the riverine flux could be revised upwards, such a revision seems 
unlikely to close the gap on the estimated outputs. It is also possible to obtain an independent constraint on the Fe-Mn oxide output of $\mathrm{Ni}$, by tying it to the slightly better known oceanic Mo budget. The input of Mo to the oceans is dominated by the dissolved load of rivers, and Archer and Vance (2008) estimate it at $2.3 \times 10^{8} \mathrm{~mol} \mathrm{yr}^{-1}$ with a $\delta^{98 / 95} \mathrm{Mo}=+0.7 \%$. Scott et al. (2008) present an analysis of the oceanic Mo budget and suggest that $35 \%$ of this input, or $8 \times 10^{7} \mathrm{~mol} \mathrm{yr}^{-1}$, is lost to the Fe-Mn oxide sink. The size of this sink for Mo is particularly well constrained by some features of the marine isotopic budget. It is well known that the Mo isotopic composition of the oceans is homogeneous and heavy, at $\delta^{98 / 95} \mathrm{Mo}=+2.3 \%$ (Nakagawa et al., 2012). This requires a light sink. Fe-Mn crusts are 3\%o lighter than seawater (Barling et al., 2001; Siebert et al., 2003), and experimental sorption of Mo to Mn oxides produces a sorbed phase that is $3 \%$ lighter than the aqueous phase (Barling and Anbar, 2004; Wasylenki et al., 2011). Thus it seems certain that the dominant light output is sorption to Mn oxides and the size of the fractionation, along with the difference between the homogeneous dissolved oceanic pool and the input, puts a relatively tight constraint on the size of the Fe-Mn oxide output for Mo. The USGS (Manheim et al., 1991) have compiled data on the chemistry of over $700 \mathrm{Fe}-\mathrm{Mn}$ crusts and nodules and these have a Ni/Mo ratio

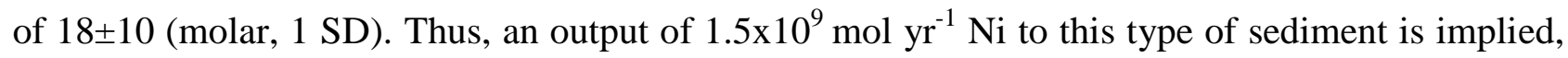
four times the dissolved riverine input. It is possible that there is some bias in the type of Fe-Mn oxide samples included in the above database so that it is, for example, not representative of dispersed Fe-Mn oxides in sediment. However, the concordance between the imbalance suggested here and that suggested by Krishnaswami (1976) based on the chemistry of pelagic sediments suggests that the conclusion is robust.

The inclusion of other potential sinks for nickel from the ocean would, of course, worsen this imbalance problem, but probably to an insignificant degree. Sediments beneath both euxinic water columns in restricted basins (significant $\mathrm{H}_{2} \mathrm{~S}$ in bottom water, e.g. Black Sea), and upwelling open ocean settings (near zero bottom-water $\mathrm{O}_{2}$ e.g. Namibian and Peru Margin) have authigenic Ni/Mo 
601 ratios close to 1 (e.g. Brumsack et al., 2006). Scott et al. (2008) estimate that these sinks represent 602 the other $65 \%$ of the total oceanic Mo output. Using the same approach as for crusts, with the above 603 authigenic Ni/Mo ratio, this implies an output of about $1.5 \times 10^{8} \mathrm{~mol} \mathrm{yr}^{-1}$, or an order of magnitude 604 less than the Fe-Mn crust output calculated in the same way.

605 These calculations, while obviously not precise, are clearly consistent with the earlier suggestion 606 (e.g. Sclater et al., 1976) that scavenging to Fe-Mn oxides is the dominant sink for Ni from the 607 oceans. Gall et al. (2013) have recently published Ni isotope data for the surfaces of a variety of 608 crusts. The dataset is quite variable, at $\delta^{60} \mathrm{Ni}=1.60 \pm 0.4 \%$ (1SD), with no clear indication of the 609 key control on this variability. But the average is very close to the seawater value obtained here. If 610 these Fe-Mn crust data are representative of the Fe-Mn oxide-associated output of Ni from the 611 oceans there is apparently little isotopic fractionation involved in this output. The lack of an 612 isotopic fractionation associated with the main output then imposes another constraint on the 613 missing input implied by the elemental imbalance discussed above. The missing source must be as 614 isotopically heavy as the dissolved pool of the oceans itself - and apparently heavier than the 615 dissolved load of rivers.

616 Of the candidates for extra inputs to the ocean, it was argued earlier that the hydrothermal source is 617 likely to be insignificant. We note that Douville et al. (2002) report high Ni concentrations in 618 hydrothermal fluids emanating from ultramafic substrate, but concentrations below detection limits 619 for fluids from basaltic substrates. There have never been any indications from depth profiles near 620 ridges that hydrothermal inputs are anything other than minor. Sclater et al. (1976) also arrive at 621 this conclusion in noting that $\mathrm{Ni} / \mathrm{Fe}$ ratios in sediment near ridges are lower than open ocean $\mathrm{Fe}-\mathrm{Mn}$ 622 nodules. Total dust input to the ocean has been estimated by Jickells et al. (2005) at $4.5 \times 10^{14} \mathrm{~g} \mathrm{yr}^{-1}$. 623 At an average Ni concentration for the continental crust of 47 ppm (Rudnick and Gao, 2003) this is 624 equivalent to a total $\mathrm{Ni}$ flux of $2.1 \times 10^{10} \mathrm{~g} \mathrm{yr}^{-1}$, or $3.6 \times 10^{8} \mathrm{~mol} \mathrm{yr}^{-1}$, close to the riverine flux of Ni. 625 However, DesBoeufs et al. (2005) estimate the Ni solubility in dust to be on the order of $2 \%$, 
suggesting that the Ni flux to the dissolved phase is unimportant. This conclusion is the same as that arrived at by others based on surface ocean dissolved Ni concentrations (e.g. Bruland, 1980; Bowie et al., 2002). Moreover, any source of Ni from dust presumably has an isotopic composition close to the lithogenic value, so that this source is unable to provide the heavy $\mathrm{Ni}$ seen in the oceans. 630 Another possibility is a diffusive flux out of sediments. Because of the strong association of Ni with 631 Mn oxides in sediment, Ni concentrations can be high in the pore fluids of sediments where the 632 reduction of Mn oxide is occurring (up to $600 \mathrm{nM}$, see Shaw et al., 1990). But our conclusion 633 earlier that the Mn oxide output is much greater than the dissolved riverine input is tied to Mo. 634 Since Mo will also be mobilised from reduced Mn oxide, this suggestion does not get around the 635 imbalance in the oceanic Ni budget with respect to that for Mo.

636 A final possibility is that mobilisation of the riverine suspended load of Ni occurs in estuaries, and 637 that this reservoir is isotopically heavy. It was noted earlier that $\mathrm{Ni}$ in the Amazon plume and the 638 Chang Jiang estuary behaves pseudo-conservatively. But it is possible that estuaries where surface 639 sediment is anoxic could reductively release $\mathrm{Ni}$ associated with Mn-oxide coatings. This 640 explanation of the imbalance problem is attractive for a number of reasons. Firstly, 95-97\% of the 641 Ni inventory of rivers is in the suspended load rather than the dissolved load (Gibbs 1973; Martin 642 and Meybeck 1979; Gaillardet et al 2003; Viers et al. 2009). Secondly, in a study of the Amazon 643 and Yukon rivers, Gibbs (1973) showed that approximately half of this suspended load reservoir of $644 \mathrm{Ni}$ is associated with oxide coatings on grains. Thirdly, the suspended load of Mo is relatively much 645 less important than for Ni. Martin and Meybeck (1979) suggest that 30\% of the total riverine load 646 of Mo is in the dissolved phase. Archer and Vance (2008) found insignificant amounts of Mo in the 647 suspended load of the Kalix and Chang Jiang. Thus, a source of Ni via the reduction of Mn oxides 648 in estuarine sediments might not come with a significant source of Mo. Finally, it is perhaps 649 noteworthy that the study of Krishnaswami (1976) also found that the oceanic Mn budget was out 650 of balance. This is confirmed by a similar approach to the Mn oxide output as taken above for $\mathrm{Ni}$, 
651 i.e. calculating it based on the Mo output to Fe-Mn oxides and the Mn/Mo ratio of Fe-Mn crusts.

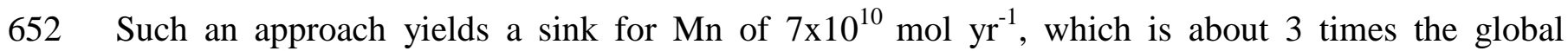
653 dissolved riverine flux given in Gaillardet et al. (2003). Thus co-release of Ni and Mn through the 654 reduction of Mn oxides could solve the imbalances of both $\mathrm{Ni}$ and $\mathrm{Mn}$.

655 The suggestion that estuarine release of suspended load Ni might solve the imbalance problem must 656 await further studies in these settings. A real problem with this suggestion, though, is the isotopic 657 heaviness of oceanic dissolved $\mathrm{Ni}$. Given the fact that the major output from seawater, as 658 represented by Fe-Mn crusts, is as heavy as the dissolved pool, the isotopic mass balance requires 659 that the overall input is also heavy. This, in turn, creates a requirement for the permanent storage of 660 a counterpart isotopically light pool of Ni somewhere on the continents. At this stage, it is not at all 661 obvious where this isotopically light reservoir might be.

\section{CONCLUDING REMARKS}

664 We have demonstrated three main features with this first dataset for the Ni isotopic compositions of 665 the dissolved phase of rivers and the oceans:

666 (1) $\mathrm{Ni}$ isotopes in the dissolved phase of rivers (discharge- and concentration-weighted $\delta^{60} \mathrm{Ni}=+0.8$ $667 \%$ ) are heavier than the average of the small dataset for silicate rocks and sediments on the 668 continent (at around 0 to $+0.3 \%$; Cameron et al., 2009). This feature is common to other transition 669 metal isotope systems such as $\mathrm{Mo}$ and $\mathrm{Cu}$ (Archer and Vance, 2008; Vance et al., 2008), and likely 670 reflects isotope fractionation in the weathering environment or during transport in rivers.

671 (2) $\mathrm{Ni}$ isotopes in the dissolved phase of the ocean are significantly heavier than this dissolved 672 riverine source, at $\delta^{60} \mathrm{Ni}=+1.44 \pm 0.15 \%$ (2SD, $\mathrm{n}=29$ from the Atlantic, Pacific and Southern 673 Oceans), necessitating either another input that is heavier than rivers, or an isotopically light output. 
(3) Oceanic dissolved $\mathrm{Ni}$ isotopes are strikingly homogeneous, with little significant difference between the surface ocean where Ni concentrations drop as low as 1.5-2 nM and the deep ocean where they are as high as 10-11 $\mathrm{nM}$. Thus, the drawdown of $\mathrm{Ni}$ in the surface ocean must occur via a process that does not involve a significant enough isotopic fractionation to yield residual heavy isotopic compositions in the surface dissolved pool.

The isotopic data put quite tight constraints on the nickel budget of the oceans, but at the moment the processes which close the budget are not clear. The main output of nickel from the oceans is via sorption to Fe-Mn oxides and this output is around a factor of five greater than the dissolved riverine input (Sclater et al., 1976; Krishnaswami, 1976). Thus, there appears to be a requirement for one or more extra sources from the elemental budget alone. Moreover, the fact that the Ni isotopic composition of this principal output, Fe-Mn crusts, is not very different (Gall et al., 2013) from the dissolved phase data reported here, suggests that an isotopically light sink is unlikely. The identity of the putative missing source is not obvious, however. Previous work (Gibbs, 1973; Martin and Meybeck, 1979) has suggested that the riverine load of nickel is overwhelmingly located in particulate material, and that this nickel is, in turn, overwhelmingly associated with surface Mn-oxide coatings. It is possible that release of this nickel in anoxic estuaries could constitute the missing isotopically heavy input. But if this is the case then there must be a sink for the counterpart isotopically-light nickel on the continents, perhaps associated with biological uptake in setting such as bogs and wetlands where methanogenesis is active (e.g. Cameron et al., 2009). Characterisation of riverine particulates, as well as sedimentary processes in anoxic estuaries, may be key to the resolution of this budgetary discussion.

The homogeneity of oceanic nickel isotopes is something of a surprise, given that the drawdown of $\mathrm{Ni}$ in the surface ocean appears to be via biological uptake (e.g. Twining et al., 2012), and the fact that such uptake usually involves a preference for the light isotope via a kinetic fractionation. Ni concentrations in the deep ocean are well known to be closely correlated with silica (e.g. Bruland, 
699 1980), and it may be that $\mathrm{Ni}$ incorporation into diatom opal, or sorption onto organic matter 700 associated with diatom opal, may dominate $\mathrm{Ni}$ drawdown in the surface ocean and be associated 701 with only a minor isotopic fractionation. Culturing work on marine phytoplankton, as well as $\mathrm{Ni}$ 702 isotopic analysis of photic zone particulate material, would greatly contribute to the resolution of 703 this discussion.

\section{Acknowledgements}

706 The authors thank Lian Zhou, Alan Whittington, Corey Archer, Nigel Harris, Eric Achterberg, Hein

707 de Baar, Wafa Abouchami and Maeve Lohan for supplying some of the samples for this work, and 708 Eric Achterberg, Maeve Lohan and M. Stinchcombe for sharing phosphate data. We thank David 709 Butterfield and the personnel onboard the $R / V$ Atlantis for technical assistance as well as Alden 710 Denny and Sanjoy Som for carrying out the CTD operations. We also thank Corey Archer and 711 Chris Coath for assistance in the Bristol laboratories. This work was supported by NERC grant 712 NE/F019092/1 and a Leverhulme Trust Research Fellowship to D. Vance. 
Abouchami W., Galer S. J. G., de Baar H. J. W., Alderkamp A. C., Middag R., Laan P., Feldmann H. and Andreae M. O. (2011) Modulation of the Southern Ocean cadmium isotope signature by ocean circulation and primary productivity. Earth Planet. Sci. Lett. 305, 83-91.

Abouchami W., Galer, S. J. G., de Baar, H. J. W., Middag, R., Klunder, M., Mezger, K., Feldmann, H. and Andreae, M. O. (2013) Cadmium isotopes in the Southern Ocean - a tracer of nutrient cycling. Geochim. Cosmochim. Acta, submitted.

Anbar A. D. and Rouxel, O. (2007) Metal stable isotopes in paleoceanography. Ann. Rev. Earth Planet. Sci. 35, 717-746.

Andersen M. B., Vance D., Archer C., Anderson R. F., Ellwood M. J. and Allen C. S. (2011) The $\mathrm{Zn}$ abundance and isotopic composition of diatom frustules, a proxy for $\mathrm{Zn}$ availability in ocean surface seawater. Earth Planet. Sci. Lett. 301, 137-145.

Archer C. and Vance D. (2008). The isotopic signature of the global riverine molybdenum flux and anoxia in the ancient oceans. Nat. Geosci. 1, 597-600.

Barling J., Arnold G. L. and Anbar A. D. (2001) Natural mass-dependent variations in the isotopic composition of molybdenum. Earth Planet. Sci. Lett. 193, 447-457.

Barling J. and Anbar A. D. (2004) Molybdenum isotope fractionation during adsorption by manganese oxides. Earth Planet. Sci. Lett. 217, 315-329.

Bennett S. A., Achterberg E. P., Connelly D. P., Statham P. J., Fones G. R. and German C.R. (2008) The distribution and stabilisation of dissolved Fe in deep-sea hydrothermal plumes. Earth Planet. Sci. Lett. 270, 157-167.

Bennett S. A., Rouxel O., Schmidt K., Garbe-Schonberg D., Statham P. J. and German C. R. (2009) Iron isotope fractionation in a buoyant hydrothermal plume, $5^{\circ} \mathrm{S}$ Mid-Atlantic Ridge. Geochim. Cosmochim. Acta 73, 5619-5634.

Bermin J., Vance D., Archer C. and Statham P. J. (2006) The determination of the isotopic composition of $\mathrm{Cu}$ and $\mathrm{Zn}$ in seawater. Chem. Geol. 226, 280-297.

Boning P., Brumsack H-J., Bottcher M. E., Schnetger B., Kriete C., Kallmeyer J. and Borchers S.L. (2004) Geochemistry of Peruvian near-surface sediments. Geochim. Cosmochim. Acta 68, 44294451.

Bowie A. R., Whitworth D. J., Achterberg E. P., Mantoura R. F. C. and Worsfold P. J. (2002) Biogeochemistry of Fe and other trace elements (Al, Co, Ni) in the upper Atlantic Ocean. Deep-Sea Res. I 49, 605-636.

Boyle E. A., Sclater F. and Edmond J. M. (1976) On the marine geochemistry of cadmium. Nature 263, 42-44.

Boyle E. A., Huested S. S. and Jones S. P. (1981) On the distribution of copper, nickel and cadmium in the surface waters of the North Atlantic and North Pacific Ocean. J. Geophys. Res. 86, 8048-8066.

Boyle E. A., Huested S. S. and Grant B. (1982) The chemical mass balance of the Amazon Plume II. Copper, nickel and cadmium. Deep-Sea Res. 29, 1355-1364.

Boyle E. A., and 20 others (2012) Geotraces IC1 (BATS) contamination-prone trace element isotopes $\mathrm{Cd}, \mathrm{Fe}, \mathrm{Pb}, \mathrm{Zn}, \mathrm{Cu}$ and Mo intercalibration. Limnol. Oceanogr. - Methods 10, 653-665.

Bruland K. W. (1980) Oceanographic distributions of cadmium, zinc, nickel, and copper in the North Pacific. Earth Planet. Sci. Lett. 47, 176-198. 
Bruland K. W. and Franks R. P. (1983) Mn, Ni, Cu, Zn and Cd in the western North Atlantic. In Trace metals in seawater (eds. C. S. Wong, E. Boyle, K. W. Bruland, J. D. Burton and E. D. Goldberg). Plenum Press, New York. pp. 395-414.

760 Bruland K. W. and Lohan M. C. (2003) Controls of Trace Metals in Seawater. In Treatise on 761 Geochemistry, vol.6 (ed. H. Elderfield). Elsevier, Amsterdam. pp. 23-47.

762

763

764

765

766

767

768

769

770

771

772

773

774

775

776

777

778

779

780

781

782

783

784

785

786

787

788

789

790

791

792

793

794

795

796

797

798

Brumsack H.-J. (2006) The trace metal content of recent organic carbon-rich sediments: Implications for Cretaceous black shale formation. Palaegeog. Palaeoclimatol. Palaeoecol. 232, 344-361.

Burd B. J. and Thomson R. E. (1994) Hydrothermal venting at Endeavour Ridge: effect on zooplankton biomass throughout the water column. Deep-Sea Res. I 41, 1407-1423.

Cameron V., Vance D., Archer C. and House C. H. (2009) A biomarker based on the stable isotopes of nickel. Proc. Natl. Acad. Sci. 106, 10944-10948.

Cowen J. P., Bertram M. A., Wakeham S. G., Thomson R. E., Lavelle W. J., Baker E. T. and Feely R. A. (2001) Ascending and descending particle flux from hydrothermal plumes at Endeavour Segment, Juan de Fuca Ridge. Deep-Sea Res. I 48, 1093-1120.

Danielsson L.-G., Magnusson B. and Westerlund S. (1985) Cadmium, copper, iron, nickel and zinc in the north-east Atlantic Ocean. Mar. Chem. 17, 23-41.

Dahlqvist R., Andersson K., Ingri J., Larsson T., Stolpe B. and Turner, D. (2007) Temporal variations of colloidal carrier phases and associated trace elements in a boreal river. Geochim. Cosmochim. Acta 71, 5339-5354.

de Baar H., Timmermans K. R., Laan P., de Porto H. H., Ober S., Blom J. J., Bakker M. C., Schilling J., Sarthou G., Smit M. G. and Klunder M. (2008) Titan: a new facility for ultraclean sampling of trace elements and isotopes in the deep oceans in the international Geotraces program. Mar. Chem. 111, 4-21.

DesBoeufs K. V., Sofikitis A., Losno R., Colin J. L. and Ausset P. (2005) Dissolution and solubility of trace metals from natural and anthropogenic aerosol particulate matter. Chemosphere 58, 159203.

Domagal-Goldman S. D., Kasting J. F., Johnston D. T. and Farquhar J. (2008) Organic haze, glaciations and multiple sulphur isotopes in the Mid-Archean Era. Earth Planet. Sci. Lett. 269, 2940.

Donat J. R., Lao K. A. and Bruland K. W. (1994) Speciation of dissolved copper and nickel in South San Francisco Bay: a multi-method aapproach. Anal. Chim. Acta 284, 547-571.

Douville E., Charlou J. L., Oelkers E. H., Bienvenu P., Colon C. F. J., Donval J. P., Fouquet Y., Prieur D. and Appriou P. (2002) The rainbow vent fluids (36 $14^{\prime}$ N, MAR): the influence of ultramafic rocks and phase separation on trace metal content in Mid-Atlantic Ridge hydrothermal fluids. Chem. Geol. 184, 37-48.

Dupont C. L., Barbeau K. and Palenik B. (2008a) Ni uptake and limitation in marine Synechoccoccus strains. App. Environ. Microbiol. 74, 23-31.

Dupont C. L., Neupane K., Shearer J. and Palenik B. (2008b) Diversity, function and evolution of genes coding for putative Ni-containing superoxide dismutases. Environ. Microbiol. 10, 1831-1843.

Edmonds J. M., Spivack A., Grant B. C., Ming-Hui H., Zexiam C., Sung C. and Xiushau Z. (1985) Chemical dynamics of the Changjiang estuary. Cont. Shelf. Res. 4, 17-36. 
Ellwood M. J. (2008) Wintertime trace metal ( $\mathrm{Zn}, \mathrm{Cu}, \mathrm{Ni}, \mathrm{Cd}, \mathrm{Pb}$ and $\mathrm{Co}$ ) and nutrient distribution in the Subantarctic Zone between $40-52^{\circ}$ S; $155-160^{\circ}$ E. Mar. Chem. 112, 107-117.

Ellwood M. J. and Hunter K. A. (2000) The incorporation of zinc and iron into the frustule of the marine diatom Thalassiosira pseudonana. Limnol. Oceanogr. 45, 1517-1524.

Filizola N., Seyler F., Mourao M. H., Arruda W., Spinola N. and Guyot J. L. (2009) Study of the variability in suspended sediment discharge at Manacapuru, Amazon River, Brazil. Latin American Journal of Sedimentology and Basin Analysis 16, 93-99.

Foster I. D. L. and Charlesworth S.M. (1996) Heavy metals in the hydrological cycle: trends and explanation. Hydrol. Proc. 10, 227-261.

Frausto da Silva J. R. R. and Williams R. J. P. (2001) The biological chemistry of the elements: the inorganic chemistry of life, $2^{\text {nd }}$ ed. Oxford University Press, Oxford.

Fujii T., Moynier F., Dauphas N. and Abe M. (2011) Theoretical and experimental investigation of nickel isotopic fractionation in species relevant to modern and ancient oceans. Geochim. Cosmochim. Acta 75, 469-482.

Gaillardet J., Dupré B., Louvat P. and Allegre C.J. (1999) Global silicate weathering and $\mathrm{CO}_{2}$ consumption rates deduced from the chemistry of large rivers. Chem. Geol. 159, 3-30.

Gaillardet J., Viers J. and Dupré B. (2003) Trace elements in river waters. In Treatise on Geochemistry, vol. 5 (ed. J. I. Drever). Elsevier, Amsterdam. pp. 225-272.

Gall L., Williams H. M., Siebert C. and Halliday A. N. (2012) Determination of mass-dependent nickel isotope compositions using double spiking and MC-ICPMS. J. Anal. Atom. Spectrom. 27, 137-145.

Gall L., Williams H. M., Siebert C., Halliday A. N., Herrington R. J. and Hein J. R. (2013) Nickel isotopic compositions of ferromanganese crusts and the constancy of deep ocean inputs and continental weathering effects over the Cenozoic. Earth Planet. Sci. Lett., in press.

Gerringa L. J. A. (1991) Problems with the estimation of the complexation characteristics of dissolved organonickel complexes. Anal. Proc. 28, 73-74.

Gibbs R. J. (1973) Mechanisms of trace metal transport in rivers. Science 180, 71-73.

Gueguen B., Rouxel O., Ponzevera E., Bekker A. and Fouquet Y. (2013) Nickel isotope variations in terrestrial silicate rocks and geological reference materials measured by MC-ICP-MS. Geostand Geoanal Res. 37, 297-317.

Haraldsson C. and Westerlund S. (1988) Trace metals in the water columns of the Black Sea and Framvaren Fjord. Mar. Chem. 23, 417-424.

Hofmann A., Bekker A., Dirks P., Gueguen B., Rumble D. and Rouxel O. J. (2013) Comparing orthomagmatic and hydrothermal mineralization models for komatiite-hosted nickel deposits in Zimbabwe using multiple-sulfur, iron, and nickel isotope data. Miner Deposita., in press.

Jenkins W. (2003) Tracers of ocean mixing. In Treatise on Geochemistry, vol. 6 (ed. H. Elderfield). Elsevier, Amsterdam. pp. 223-246.

Jickells T.D. and 18 others (2005) Global iron connections between desert dust, ocean biogeochemistry and climate. Science 308, 67-71.

John S. G. and Adkins J. F. (2010) Analysis of dissolved iron isotopes in seawater. Mar. Chem. 119, 65-76.

John S. G, Geis R. W., Saito M.A. and Boyle E.A. (2007) Zinc isotope fractionation during high- 
affinity and low-affinity zinc transport by the marine diatom Thalassiosira oceanica. Limnol. Oceanogr. 52, 2710-2714.

Kasting J. F. (2005) Methane and climate during the Precambrian era. Precam. Res. 137, 119-129.

Kelley D. S., Baross J. A. and Delaney J. R. (2002) Volcanoes, fluids, and life at mid-ocean ridge spreading centers. Annu. Rev. Earth Planet. Sci. 30, 385-491.

Konhauser K. O., Pecoits E., Lalonde S. V., Papineau D., Nisbet E. G., Barley M. E., Arndt N. T., Zahnle K. and Kamber B.S. (2009) Oceanic nickel depletion and a methanogen famine before the Great Oxidation Event. Nature 458, 750-753.

Koshikawa M. K., Takamatsu T., Takada J., Zhu M., Xu B., Chen Z., Marakami S., Xu K. and Watanabe M. (2007) Distributions of dissolved and particulate elements in the Yangtze estuary in 1997-2002: Background data before the closure of the Three Gorges Dam. Est. Coast. Shelf Sci. 71, 26-36.

Krishnaswami S. (1976) Authigenic transition elements in Pacific pelagic clays. Geochim. Cosmochim. Acta 40, 425-434.

Krüger M., Meyerdierks A., Glöckner F. O., Amann R., Widdel F., Kube M., Reinhardt R., Kahnt J., Böcher R., Thauer R. K. and Shima S. (2003) A conspicuous nickel protein in microbial mats that oxidize methane anaerobically. Nature 426, 878-881.

Lai X., Norisuye K., Mikata M., Minami T., Bowie A. R. and Sohrin Y. (2008) Spatial and temporal distribution of $\mathrm{Fe}, \mathrm{Ni}, \mathrm{Cu}$ and $\mathrm{Pb}$ along $140^{\circ} \mathrm{W}$ in the Southern Ocean during austral summer 2001/02. Mar. Chem. 111, 171-183.

Little S. H., Vance D., Walker-Brown C. and Landing W. M. (2013) The oceanic mass balance of $\mathrm{Cu}$ and $\mathrm{Zn}$ isotopes, investigated by analysis of their inputs and oxic output in ferromanganese crusts. Geochim. Cosmochim. Acta, submitted.

Lohan M. C., Statham P. J. and Crawford D. W. (2002) Total dissolved zinc in the upper water column of the subarctic NorthEast Pacific. Deep-Sea Res. II 49, 5793-5808.

Löscher B. M. (1999) Relationships among Ni, Cu, Zn and major nutrients in the Southern Ocean. Mar. Chem. 67, 67-102.

Lupton J. E., Delaney J. R., Johnson H. P. and Tivey M. K. (1985) Entrainment and vertical transport of deep-ocean water by buoyant hydrothermal plumes. Nature 316, 621-623.

Mackey D. J., O'Sullivan J. E., Watson R. J. and Dal Pont G. (2002) Trace metals in the Western Pacific, temporal and spatial variability in the concentrations of $\mathrm{Cd}, \mathrm{Cu}, \mathrm{Mn}$ and Ni. Deep-Sea Res. I 49, 2241-2259.

Manheim F. and Lane-Bostwick C. (1991) Chemical composition of ferromanganese crusts in the world ocean: a review and comprehensive database. Open-File Report 89-020, U.S. Geological Survey, Woods Hole, MA.

Martin J-M. and Meybeck M. (1979) Elemental mass-balance of material carried by major world rivers. Mar. Chem. 7, 173-206.

Meade R. H., Rayol J. M., da Conceicao S. C. and Natividade J. R. G. (1991) Backwater effects in the Amazon River Basin of Brazil. Environ. Geol. Water Sci. 18, 105-114.

Morley N. H., Statham P.J. and Burton, J. F. (1993) Dissolved trace metals in the southwest Indian Ocean. Deep-Sea Res. I 40, 1043-1062.

Nakagawa Y., Takano S., Firdaus M. L., Norisuye K., Hirata T., Vance D. and Sohrin Y. (2012)

The molybdenum isotopic composition of the modern ocean. Geochem. J. 46, 131-141. 
Norisuye K., Ezoe M., Nakatsuka S., Umetani S. and Sohrin Y. (2007) Distribution of bioactive trace metals (Fe, Cu, Ni, Cu, Zn and $\mathrm{Cd})$ in the Sulu Sea and its adjacent seas. Deep-Sea Res. II 54, 14-37.

Peel K., Weiss D. and Sigg L. (2009) Zinc isotope composition of settling particles as a proxy for biogeochemical processes in lakes: insights from the eutrophic Lake Greifen, Switzerland. Limnol. Oceanogr. 54, 1699-1708.

Pekka L., Ingri J., Widerlund A., Mokrotovarova O., Riabtseva M. and Öhlander B. (2004) Geochemistry of the Kola River, northwestern Russia. App. Geochem. 19, 1975-1995.

Pontér C., Ingri J., Burman J.-O. and Boström K. (1990) Temporal variations in dissolved and suspended iron and manganese in the Kalix River, northern Sweden. Chem. Geol. 81, 121-131.

Price N. M. and Morel F. M. M. (1991) Colimitation of phytoplankton growth by nickel and nitrogen. Limnol. Oceanogr. 36, 1071-1077.

\section{Ragsdale S.W. (2009) Nickel-based enzyme systems. J. Biol. Chem. 284, 18571-18575.}

Rondeau B., Cossa D., Gagnon P., Pham T. T. and Surette C. (2005) Hydrological and bieogeochemical dynamics of the minor and trace elements in the St. Lawrence River. App. Geochem. 20, 1391-1408.

Rudnick R. L. and Gao S. (2003) Composition of the continental crust. In Treatise on Geochemistry, vol. 3 (ed. R. L. Rudnick). Elsevier, Amsterdam. pp. 1-64.

Saager P. M., De Baar H. J. W. and Howland R. J. (1992) Cd, Zn, Ni and Cu in the Indian Ocean. Deep-Sea Res. 39, 9-35.

Saager P. M., de Baar H. J. W., de Jong J. T. M., Nolting R. F. and Schijf J. (1997) Hydrography and local sources of dissolved trace metals $\mathrm{Mn}, \mathrm{Ni}, \mathrm{Cu}$ and $\mathrm{Cd}$ in the northeast Atlantic Ocean. Mar. Chem. 57, 195-216.

Sclater F. R., Boyle E., Edmond J. M. (1976) On the marine geochemistry of nickel. Earth Planet. Sci. Lett. 31, 119-128.

Scott C., Lyons T. W., Bekker A., Shen Y., Poulton S. W., Chu X., Anbar A. D. (2008) Tracing the stepwise oxygenation of the Proterozoic Ocean. Nature 452, 456-459.

Sharma M., Polizzotto M. and Anbar A.D. (2001) Iron isotopes in hot springs along the Juan de Fuca Ridge. Earth Planet. Sci. Lett. 194, 39-51.

Shaw T. J., Gieskes J. M., Jahnke R. A. (1990) Early diagenesis in differing depositional environments: the response of transition metals in pore water. Geochim. Cosmochim. Acta 54, 1233-1246.

Shiller A. M., and Boyle E.A. (1987) Variability of dissolved trace metals in the Mississippi River. Geochim. Cosmochim. Acta 51, 3273-3277.

Shiller A. M. (1997) Dissolved trace elements in the Mississippi River: seasonal, interannual, and decadal variability. Geochim. Cosmochim. Acta 61, 4321-4330.

Shima S., Krueger M., Weinert T., Demmer U., Kahnt J., Thauer R. K. and Ermler U. (2012) Structure of a methyl-coenzyme $M$ reductase from Black Sea mats that oxidize methane anaerobically. Nature 481, 98-101.

Siebert C., Nägler T., von Blanckenburg F. and Kramers J.D. (2003) Molybdenum isotope records as a potential new proxy for paleoceanography. Earth Planet. Sci. Lett. 211, 159-171.

Stallard R. F. and Edmond J. M. (1983) Geochemistry of the Amazon 2. The influences of geology and weathering environment on the dissolved load. J. Geophys. Res. 88, 9671-9688. 
Thauer R. K. (1998) Biochemistry of methanogenesis: a tribute to Marjory Stephenson. Microbiol. 928 144, 2377-2406.

929 Thomson R. E., Burd B. J., Dolling A. G., Gordon R. L. and Jamieson G. S. (1992) The deep 930 scattering layer associated with the Endeavour Ridge hydrothermal plume. Deep-Sea Res. 39, 5593173.

932 Turner A. and Martino M. (2006) Modelling of the equilibrium speciation of nickel in the Tweed 933 Estuary, UK: voltammetric determinations and simulations using WHAM. Mar. Chem. 102, 198934207.

935 Tribovillard N., Algeo T. J., Lyons T. and Riboulleau A. (2006) Trace metals as paleoredox and 936 paleoproductivity proxies: an update. Chem. Geol. 232, 12-32.

937 Twining B. S., Baines S. B., Fisher N. S. and Landry M.R. (2004) Cellular iron contents during the 938 Southern Ocean Iron Experiment (SOFEX). Deep-Sea Res. I 51, 1827-1850.

939 Twining B. S., Baines S. B., Vogt S. and Nelson D. M. (2012) Role of diatoms in nickel 940 biogeochemistry in the ocean, Glob. Biogoechem. Cyc. 26, GB4001, doi: 10.1029/2011GB004233.

941 Williams R. J. P. and Frausto da Silva J. J. R. (2003) Evolution was chemically constrained. $J$. 942 Theor. Biol. 220, 323-343.

943 Vance D., Archer C., Bermin J., Perkins J., Statham P. J., Lohan M. C., Ellwood M. J. and Mills R. 944 A. (2008) The copper isotope geochemistry of rivers and the oceans. Earth Planet. Sci. Lett. 274, 945 204-213.

946 Vance D., Zhao Y., Cullen J. T. and Lohan M. C. (2012) Zinc isotopic data from the NE Pacific 947 reveals shallow recycling. Mineralogical Magazine 76, 2486. dissolved organic material in seawater using cathodic stripping voltammetry. Sci. Total Environ. 60, 185-195.

951 Viers J., Dupre B. and Gaillardet J. (2009) Chemical composition of suspended sediments in World 952 Rivers: New insights from a new database. Sci. Total Environ. 407, 853-868.

953 Wasylenki L. E., Weeks C. L., Bargar J. R., Spiro T. G., Hein J. R. and Anbar A. D. (2011) The 954 molecular mechanism of Mo isotope fractionation during adsorption to birnessite. Geochim. 955 Cosmochim. Acta 75, 5019-5031.

956 Xue H. B., Jansen S., Prasch A. and Sigg L. (2001) Nickel speciation and complexation kinetics in 957 freshwater by ligand exchange and DPCSV. Env. Sci. Tech. 35, 539-546.

958 Yeats P. A. and Campbell J. A. (1983) Nickel, copper, cadmium and zinc in the northwest Atlantic 959 Ocean. Mar. Chem. 12, 43-58.

960 Yeats P. A., Westerlund S. and Flegal A. R. (1995) Cadmium, copper and nickel distributions at 961 four stations in the eastern central and south Atlantic. Mar. Chem. 49, 283-293.

962 Zhao Y., Vance D., Abouchami W., de Baar H. J. W. (2013) Zinc isotopes in the Southern Ocean 963 a tracer of biogeochemical cycling? Geochim. Cosmochim. Acta, in press. 


\section{FIGURE CAPTIONS}

Figure 1: Frequency distribution of $\mathrm{Ni}$ isotope compositions for all river and seawater samples measured here, with frequency for each individual dataset (rivers, seawater) normalised to the total number of measurements.

Figure 2: Nickel isotope data for rivers plotted against reciprocal concentration. Error bars are for long-term reproducibility of standards analysed using the double spike method. The horizontal black line and grey band give the average and 1SD of $\mathrm{Ni}$ isotope compositions of samples of continental silicate rocks (Cameron et al., 2009).

Figure 3: Nickel isotopic and concentration data for the Iceland Basin, North Atlantic. Uncertainties on isotopic data correspond to the long-term reproducibility of standards using the double spike procedure.

Figure 4: Nickel isotopic and concentration data for the North Pacific. Filled squares are for the depth profile at $\mathbf{4 7}^{\circ} \mathrm{N}, \mathbf{1 2 9}^{\circ} \mathrm{W}$. Open squares are for $1000 \mathrm{~m}$ samples at $50-52^{\circ} \mathrm{N}, 133-145^{\circ} \mathrm{W}$ Uncertainties on isotopic data correspond to the long-term reproducibility of standards using the double spike procedure.

Figure 5: Nickel isotopic and concentration data for the Atlantic Sector of the Southern Ocean. Filled squares are for the depth profile at Station PS71-104 in the Polar Front Zone $\left(\sim 48^{\circ} \mathrm{S}\right)$. Open squares are for surface samples further south, at $52-60^{\circ} \mathrm{S}$.

Figure 6: Nickel concentration data (filled squares) for all North Pacific data presented here, for the Iceland Basin depth profile and for the Southern Ocean (partial) depth profile, compared with data from the literature (open diamonds). Literature data for the North Pacific are for the three depth 
991 profiles in Bruland (1980). For the Iceland Basin data are shown for two stations close to that 992 presented here (Yeats and Campbell 1983; Danielsson et al., 1985). For the Southern Ocean Polar 993 Front Zone, the literature data plotted are a composite of 6 stations in Löscher (1999).

995 Figure 7: Nickel concentration data versus phosphate where available (Southern Ocean phosphate 996 data from Abouchami et al., 2011, 2013, Iceland Basin data from E. Achterberg, pers. comm., and 997 NE Pacific 1999-2001 data from M. Lohan, pers. comm.). Symbols as in Figure 3, except that 998 literature data (open diamonds) are split into Atlantic (green) and Pacific (black). The line shown is 999 fitted to all the data presented here. Data from the greatest depths in the North Pacific (Bruland, 1000 1980) is well-known to deviate from a linear relationship due to the fact that phosphate usually 1001 presents a maximum at 1000-1500m whereas Ni continues increasing below this depth, reaching a 1002 maximum, if present, much deeper in the water column. Virtually all the data in this paper are from 1003 above $1500 \mathrm{~m}$.

1005 Figure 8: Nickel isotope data for rivers versus $\mathrm{Cu}$ isotope data where available (Vance et al., 2008). 1006 Symbols as in Figure 1. For all samples except two, the $\mathrm{Cu}$ and $\mathrm{Ni}$ isotopic analyses were done on 1007 samples from the same bottles. The two exceptions are the Nile samples, where $\mathrm{Cu}$ and $\mathrm{Ni}$ analyses 1008 for the main Nile (dry and wet season) come from different samples collected at nearby localities. 1009 The grey box gives the range (average $\pm 1 \mathrm{SD}$ ) of $\mathrm{Cu}$ and $\mathrm{Ni}$ isotope compositions of samples of 1010 continental silicate rocks (Cameron et al., 2009; $\mathrm{Cu}$ data compiled in Little et al., 2013). With the 1011 exception of the Brahmaputra sample, which has an anomalously light $\mathrm{Ni}$ isotope composition 1012 given its $\delta^{65} \mathrm{Cu}$, the $\mathrm{R}^{2}$ for the data is 0.75 .

1014 Figure 9: Nickel isotope data for seawater versus phosphate and silica concentrations. See caption 1015 to Figure 7 for the sources of the major nutrient data. 
Table 1: Nickel concentration and isotope data for rivers.

\begin{tabular}{|c|c|c|c|c|c|c|c|c|}
\hline \multirow[b]{2}{*}{ River } & \multirow[b]{2}{*}{ Tributary or Location } & \multirow[b]{2}{*}{ Sample ID } & \multirow[b]{2}{*}{$\begin{array}{c}{[\mathrm{Ni}]} \\
\left(\mathrm{nmol} \mathrm{kg}^{-1}\right) \\
\end{array}$} & \multirow[b]{2}{*}{$\begin{array}{c}\delta^{60} \mathrm{Ni} \\
(\%)\end{array}$} & \multirow[b]{2}{*}{$2 \sigma^{1}$} & \multicolumn{3}{|c|}{ River Averages } \\
\hline & & & & & & $\begin{array}{c}{[\mathrm{Ni}]} \\
\left(\mathrm{nmol} \mathrm{kg}^{-1}\right)\end{array}$ & $\begin{array}{c}\delta^{60} \mathrm{Ni} \\
(\%)\end{array}$ & $\begin{array}{c}\text { Discharge } \\
\left(10^{12} \text { litre } \mathrm{yr}^{-1}\right)\end{array}$ \\
\hline \multirow[t]{4}{*}{ Amazon } & Negro at Manaus & Negro 2 & 2.2 & 0.31 & 0.07 & & & \\
\hline & Negro at Manaus & Negro 3 & 2.7 & 0.41 & 0.06 & 2.5 & 0.36 & 946 \\
\hline & Solimoes at Manaus & Sol 1 & 9.4 & 0.88 & 0.05 & & & \\
\hline & Solimoes at Manaus & Sol 2 & 9.5 & 0.88 & 0.07 & 9.5 & 0.88 & 3248 \\
\hline Tocantins & Belem & TOC1 & 4.5 & 0.88 & 0.09 & 4.5 & 0.88 & 372 \\
\hline \multirow[t]{3}{*}{ Chang Jiang } & Upstream Wuhan & $\mathrm{CJ}-1$ & 6.3 & 1.34 & 0.05 & & & \\
\hline & Upstream Wuhan & $\mathrm{CJ}-2$ & 7.7 & 1.19 & 0.04 & & & \\
\hline & Wuhan & $\mathrm{CJ}-5$ & 6.0 & 1.27 & 0.04 & 6.6 & 1.27 & 928 \\
\hline \multirow[t]{2}{*}{ Main Nile } & El Gaili, Sudan (wet) & Sample 5 & 13.6 & 0.84 & 0.02 & & & \\
\hline & Sayala, Sudan (dry) & АТВ01/5 & 13.9 & 0.99 & 0.05 & 13.7 & 0.91 & 83 \\
\hline Missouri & Columbia & Mizz1 & 35.0 & 0.68 & 0.03 & 35.0 & 0.68 & 580 \\
\hline Brahmaputra & Tezpur, Assam & Brahm & 5.1 & 0.29 & 0.07 & 5.1 & 0.29 & 1003 \\
\hline Ottawa & Chenaux & Aylmer & 12.3 & 0.82 & 0.07 & 12.3 & 0.82 & 337 \\
\hline \multirow[t]{3}{*}{ Kalix } & Angesa & $\mathrm{Kx} 2$ & 4.1 & 0.73 & 0.07 & & & \\
\hline & Kalix & $\mathrm{Kx} 4$ & 5.6 & 1.00 & 0.08 & & & \\
\hline & Kalix & $\mathrm{Kx} 5$ & 5.6 & 0.97 & 0.07 & 5.1 & 0.90 & 9 \\
\hline
\end{tabular}

${ }^{\mathrm{T}}$ Measured internal 2 sigma - see Methods for reproducibility.

${ }^{2}$ Discharges as in Gaillardet et al. (1999), Pontér et al. (1990), Meade et al. (1991) and Filizola et al. (2009). Note that discharge given for

Missouri is for the entire Mississippi system, that for the Brahmaputra is for the entire Ganges-Brahmaputra system and that for the

Ottawa is for the entire St. Lawrence system. 
Table 2: Nickel concentration and isotope data for seawater samples.

\begin{tabular}{|c|c|c|c|c|c|c|}
\hline Sample & Latitude & Longitude & $\begin{array}{l}\text { Depth } \\
\text { (m) }\end{array}$ & $\begin{array}{c}{[\mathrm{Ni}]} \\
(\mathrm{nmol} / \mathrm{kg})\end{array}$ & $\begin{array}{c}\delta^{60} \mathrm{Ni} \\
(\%)\end{array}$ & $2 \sigma^{1}$ \\
\hline \multicolumn{7}{|c|}{ RRS Cruise 354 Station 28, Iceland Basin, North Atlantic (Aug 2010) } \\
\hline CTD T027 - 13 & $61^{\circ} 15.19^{\prime} \mathrm{N}$ & $20^{\circ} 45.82^{\prime} \mathrm{W}$ & 20 & 3.13 & 1.52 & 0.05 \\
\hline CTD T027 - 10 & $61^{\circ} 15.19^{\prime} \mathrm{N}$ & $20^{\circ} 45.82^{\prime} \mathrm{W}$ & 50 & 3.54 & 1.53 & 0.05 \\
\hline CTD T027 - 7 & $61^{\circ} 15.19^{\prime} \mathrm{N}$ & $20^{\circ} 45.82^{\prime} \mathrm{W}$ & 150 & 3.64 & 1.52 & 0.04 \\
\hline CTD T027 - 5 & $61^{\circ} 15.19^{\prime} \mathrm{N}$ & $20^{\circ} 45.82^{\prime} \mathrm{W}$ & 500 & 3.61 & 1.53 & 0.03 \\
\hline CTD T027 - 4 & $61^{\circ} 15.19^{\prime} \mathrm{N}$ & $20^{\circ} 45.82^{\prime} \mathrm{W}$ & 830 & 4.12 & 1.34 & 0.06 \\
\hline CTD T027 - 3 & $61^{\circ} 15.19^{\prime} \mathrm{N}$ & $20^{\circ} 45.82^{\prime} \mathrm{W}$ & 1300 & 4.07 & 1.41 & 0.06 \\
\hline CTD T027 - 24 & $61^{\circ} 15.19^{\prime} \mathrm{N}$ & $20^{\circ} 45.82^{\prime} \mathrm{W}$ & 2210 & 4.06 & 1.48 & 0.04 \\
\hline \multicolumn{7}{|c|}{ US Geotrace cruise ICl, R/V Knorr, Tropical North Atlantic (June 2008) } \\
\hline GPrI 20 & $31^{\circ} 40^{\prime} \mathrm{N}$ & $64^{\circ} 10^{\prime} \mathrm{W}$ & 1000 & 4.91 & 1.37 & 0.04 \\
\hline \multicolumn{7}{|c|}{ Geotraces-IPY cruise ANT XXIV/3, Polarstern, Atlantic Sector, Southern Ocean (Feb-Apr 2008) } \\
\hline PS71-109 & $51.67^{\circ} \mathrm{S}$ & 0.00 & $2-5$ & 6.51 & 1.43 & 0.05 \\
\hline PS71-111 & $52.17^{\circ} \mathrm{S}$ & $0.54^{\circ} \mathrm{W}$ & $2-5$ & 6.35 & 1.45 & 0.07 \\
\hline PS71-126 & $57.21^{\circ} \mathrm{S}$ & 0.00 & $2-5$ & 6.36 & 1.47 & 0.04 \\
\hline PS71-136 & $60.24^{\circ} \mathrm{S}$ & 0.00 & $2-5$ & 6.27 & 1.44 & 0.05 \\
\hline PS71-104-2-24 & $47^{\circ} 39.36 ' S$ & $4^{\circ} 15.7^{\prime} \mathrm{E}$ & 15 & 5.77 & 1.45 & 0.05 \\
\hline PS71-104-2-22 & $47^{\circ} 39.36 ' \mathrm{~S}$ & $4^{\circ} 15.7^{\prime} \mathrm{E}$ & 50 & 5.87 & 1.58 & 0.05 \\
\hline PS71-104-2-22; repeat & $47^{\circ} 39.36 ' \mathrm{~S}$ & $4^{\circ} 15.7^{\prime} \mathrm{E}$ & 50 & 5.71 & 1.54 & 0.04 \\
\hline PS71-104-2-20 & $47^{\circ} 39.36 ' \mathrm{~S}$ & $4^{\circ} 15.7^{\prime} \mathrm{E}$ & 101 & 5.56 & 1.51 & 0.06 \\
\hline PS71-104-2-18 & $47^{\circ} 39.36 ' \mathrm{~S}$ & $4^{\circ} 15.7^{\prime} \mathrm{E}$ & 202 & 5.67 & 1.47 & 0.05 \\
\hline PS71-104-2-16 & $47^{\circ} 39.36 ' \mathrm{~S}$ & $4^{\circ} 15.7^{\prime} \mathrm{E}$ & 301 & 6.13 & 1.47 & 0.05 \\
\hline P71-S104-2-14 & $47^{\circ} 39.36 ' \mathrm{~S}$ & $4^{\circ} 15.7^{\prime} \mathrm{E}$ & 399 & 6.24 & 1.46 & 0.06 \\
\hline PS71-104-2-11 & $47^{\circ} 39.36 ' \mathrm{~S}$ & $4^{\circ} 15.7^{\prime} \mathrm{E}$ & 998 & 7.02 & 1.40 & 0.03 \\
\hline PS71-S104-2-9 & $47^{\circ} 39.36 ' \mathrm{~S}$ & $4^{\circ} 15.7^{\prime} \mathrm{E}$ & 1500 & 6.81 & 1.42 & 0.05 \\
\hline \multicolumn{7}{|c|}{ EAGER Cruise AT15-47, R/V Atlantis, Juan de Fuca Ridge, NE Pacific Ocean (June 2009) } \\
\hline E22 & $47^{\circ} 56.00^{\prime} \mathrm{N}$ & $129^{\circ} 04.30^{\prime} \mathrm{W}$ & 100 & 5.54 & 1.32 & 0.05 \\
\hline $\mathrm{E} 20$ & $47^{\circ} 56.00^{\prime} \mathrm{N}$ & $129^{\circ} 04.30^{\prime} \mathrm{W}$ & 300 & 6.63 & 1.42 & 0.03 \\
\hline E18 & $47^{\circ} 56.00^{\prime} \mathrm{N}$ & $129^{\circ} 04.30^{\prime} \mathrm{W}$ & 800 & 8.87 & 1.36 & 0.02 \\
\hline E16 & $47^{\circ} 56.00^{\prime} \mathrm{N}$ & $129^{\circ} 04.30^{\prime} \mathrm{W}$ & 1300 & 9.86 & 1.41 & 0.03 \\
\hline E14 & $47^{\circ} 56.00^{\prime} \mathrm{N}$ & $129^{\circ} 04.30^{\prime} \mathrm{W}$ & 1800 & 11.2 & 1.21 & 0.02 \\
\hline E12 & $47^{\circ} 56.00^{\prime} \mathrm{N}$ & $129^{\circ} 04.30^{\prime} \mathrm{W}$ & 2300 & 10.6 & 1.43 & 0.02 \\
\hline \multicolumn{7}{|l|}{ NE Pacific (1999-2001) } \\
\hline 26P1000 & $50^{\circ} \mathrm{N}$ & $145^{\circ} \mathrm{W}$ & 1000 & 9.48 & 1.45 & 0.04 \\
\hline C1000 - (Haida Eddy centre) & $51.15^{\circ} \mathrm{N}$ & $133.60^{\circ} \mathrm{W}$ & 1000 & 9.47 & 1.42 & 0.03 \\
\hline E1000 - (Haida Eddy edge) & $51.35^{\circ} \mathrm{N}$ & $133.50^{\circ} \mathrm{W}$ & 1000 & 9.36 & 1.47 & 0.03 \\
\hline
\end{tabular}

${ }^{\mathrm{T}}$ Measured internal 2 sigma - see Methods for reproducibility. 
Cameron and Vance - Figure 1

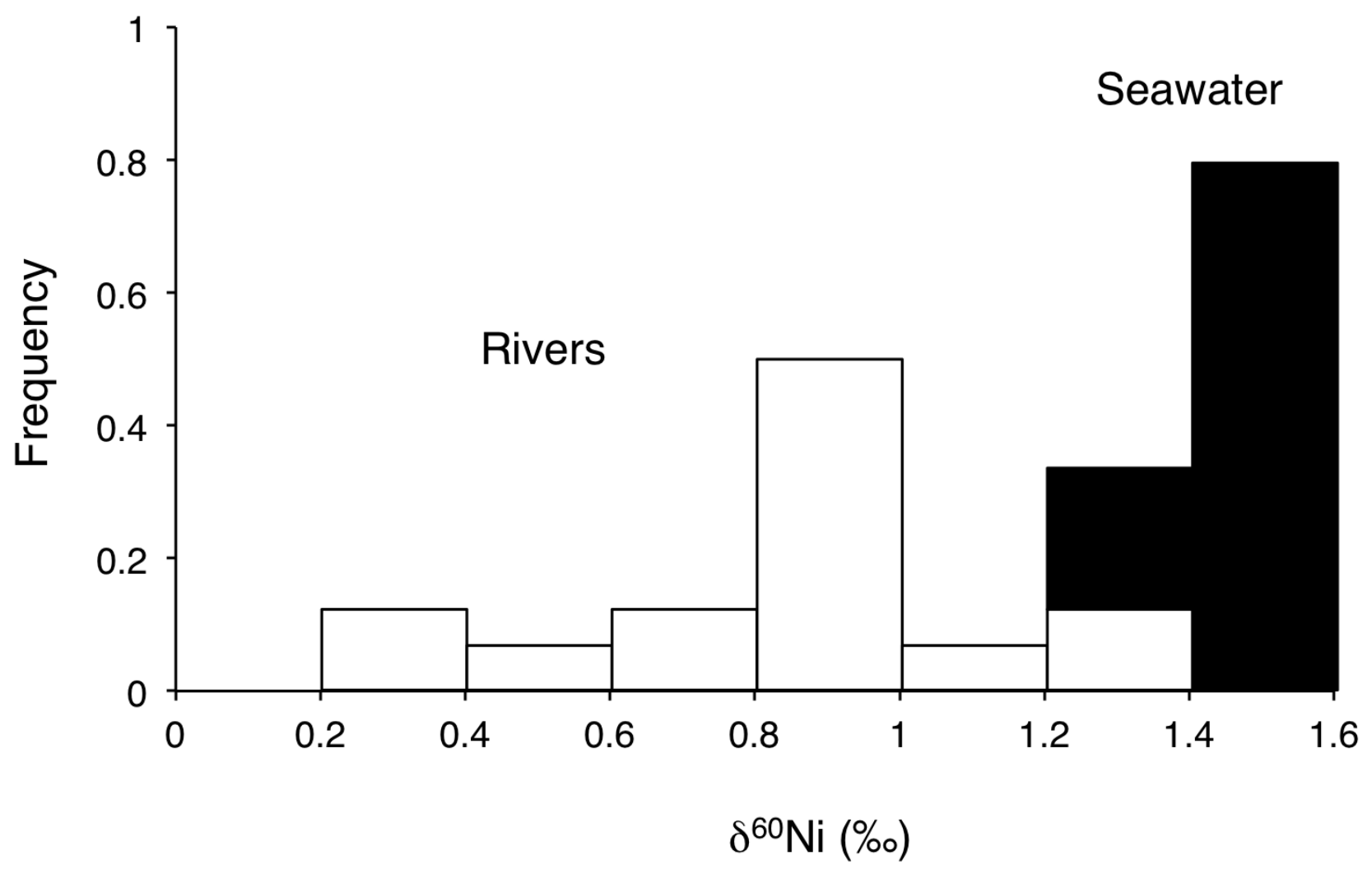


Cameron and Vance - Figure 2

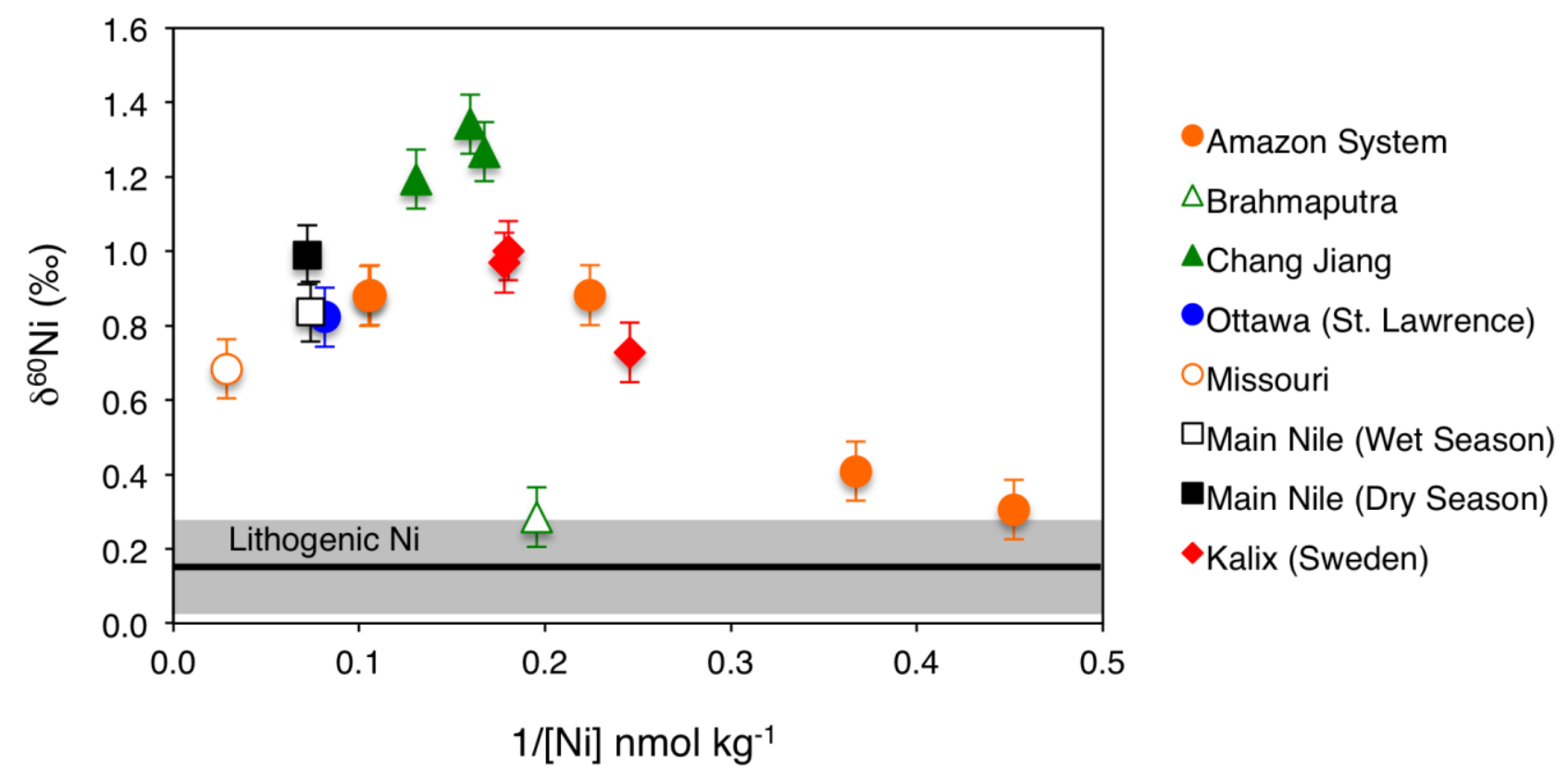




\section{Cameron and Vance - Figure 3}

Iceland Basin, North Atlantic
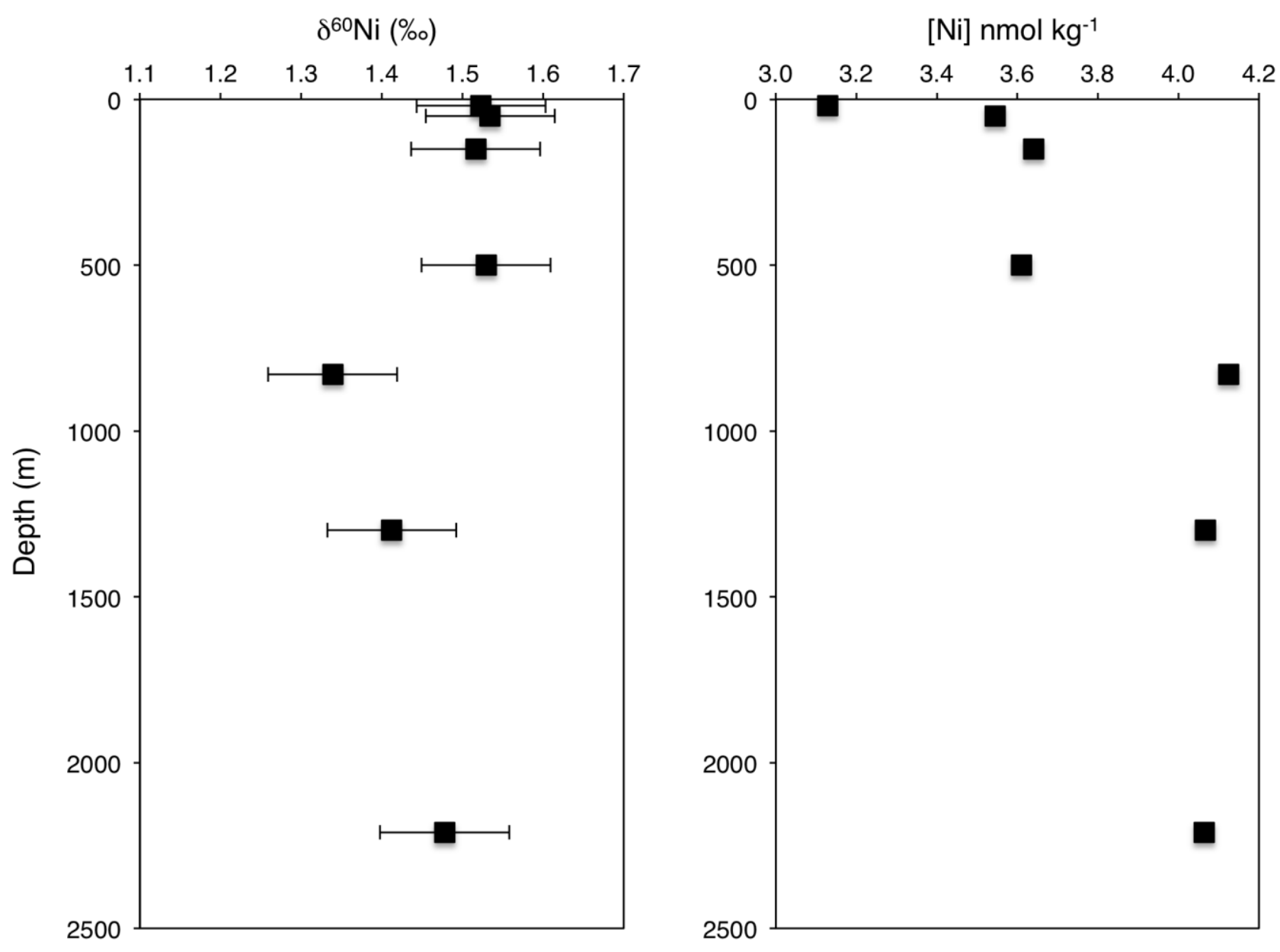


\section{Cameron and Vance - Figure 4}

North Pacific

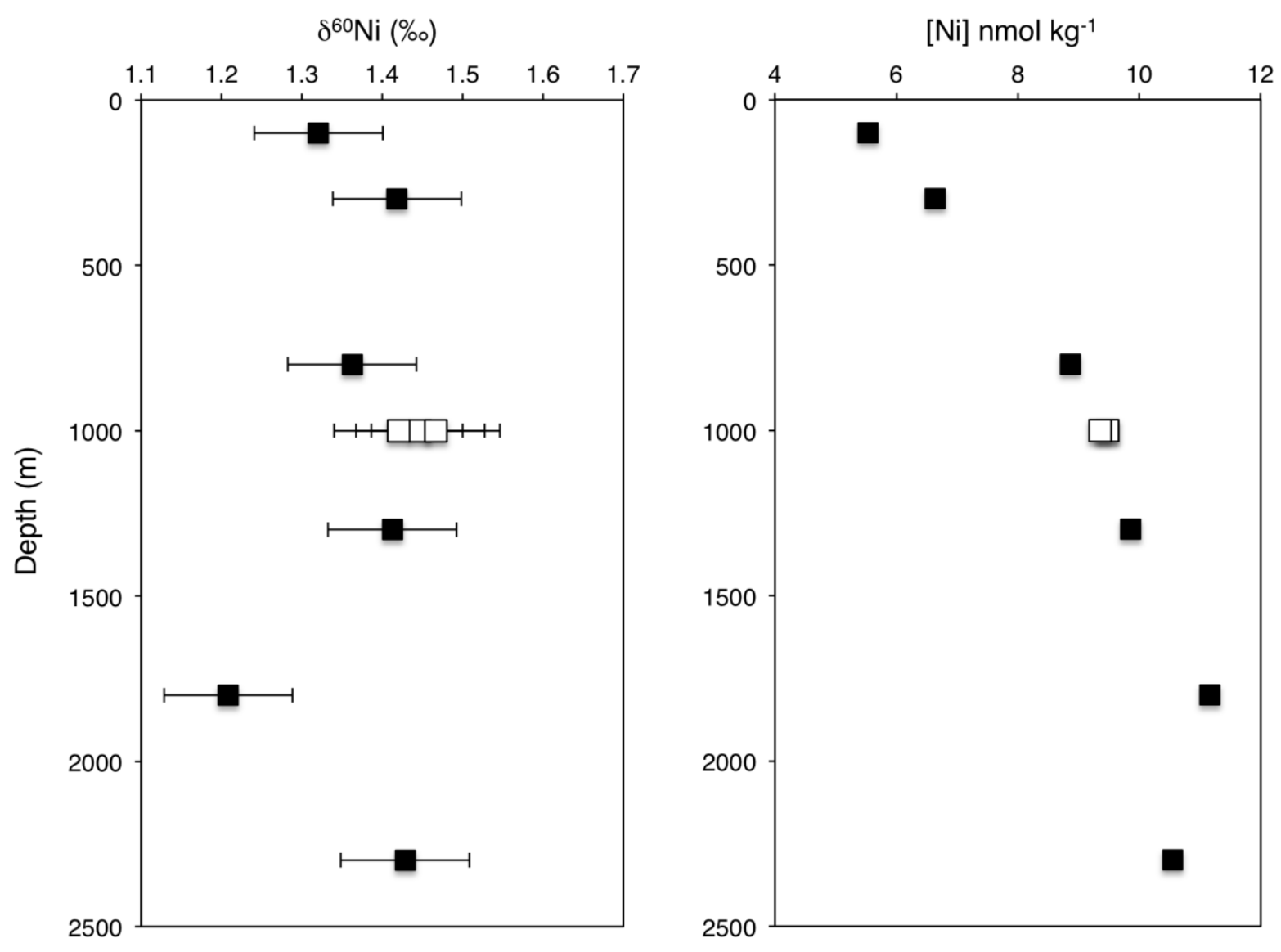




\section{Cameron and Vance - Figure 5}

Southern Ocean, Atlantic Sector
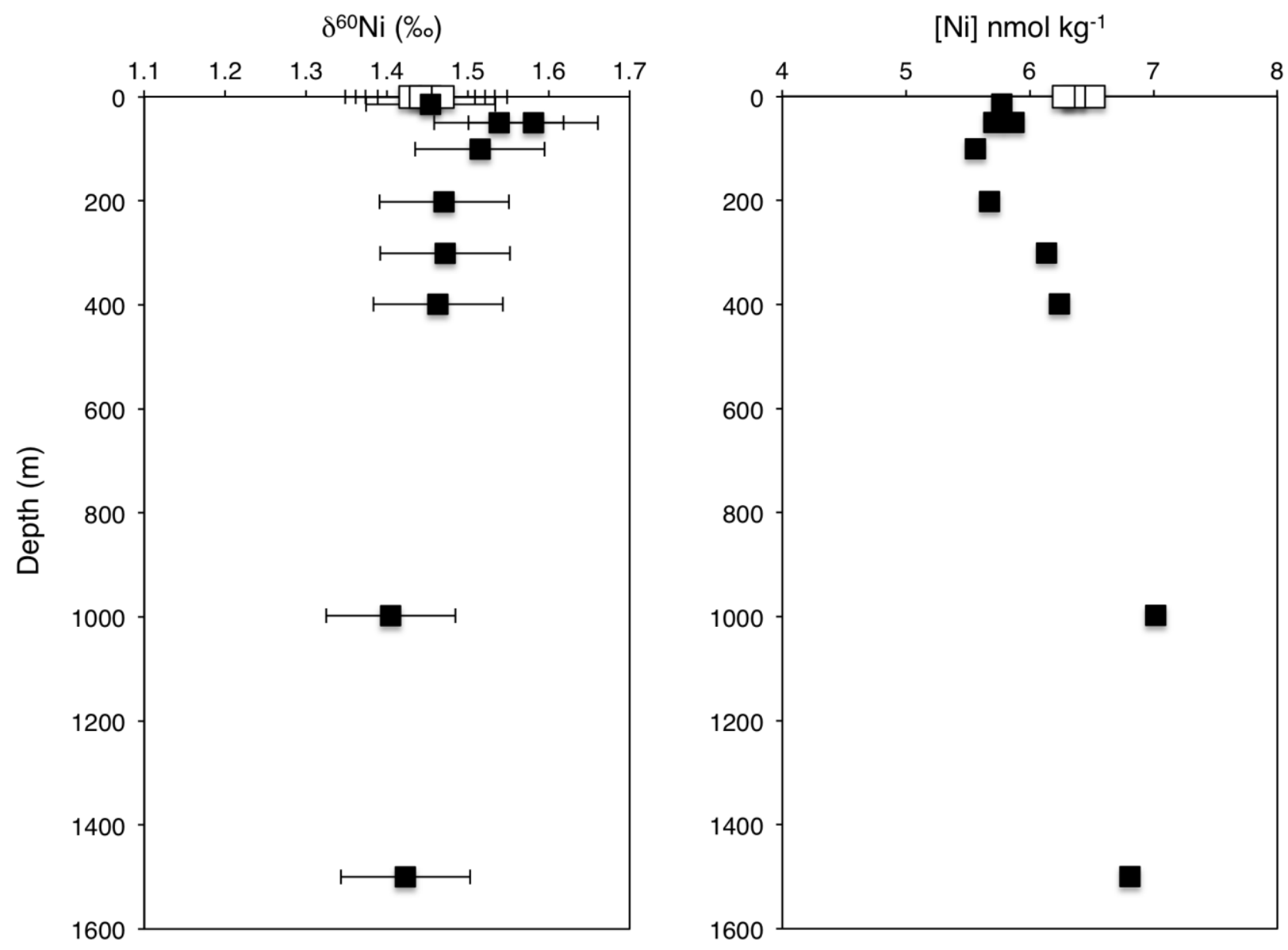


\section{Cameron and Vance - Figure 6}

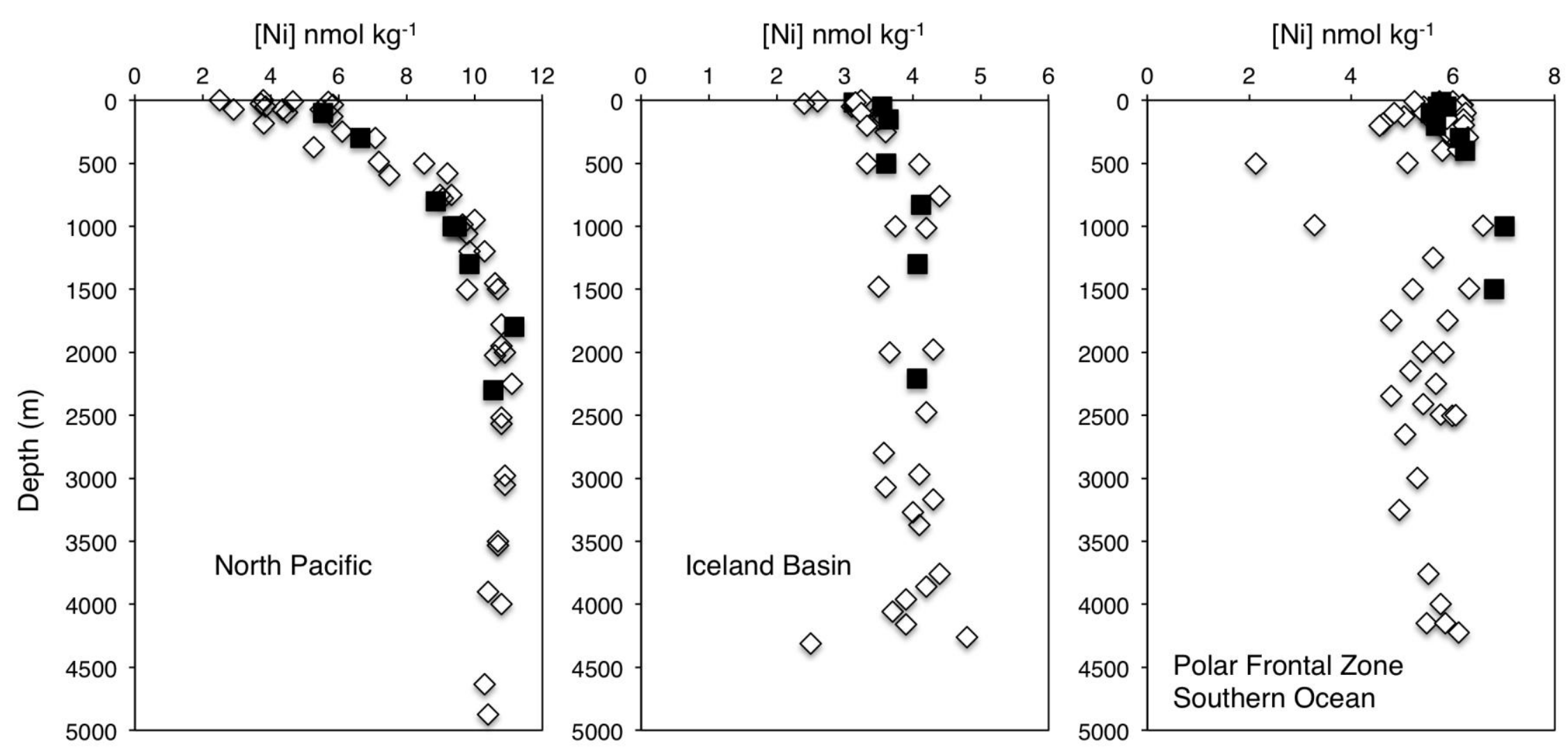


Cameron and Vance - Figure 7

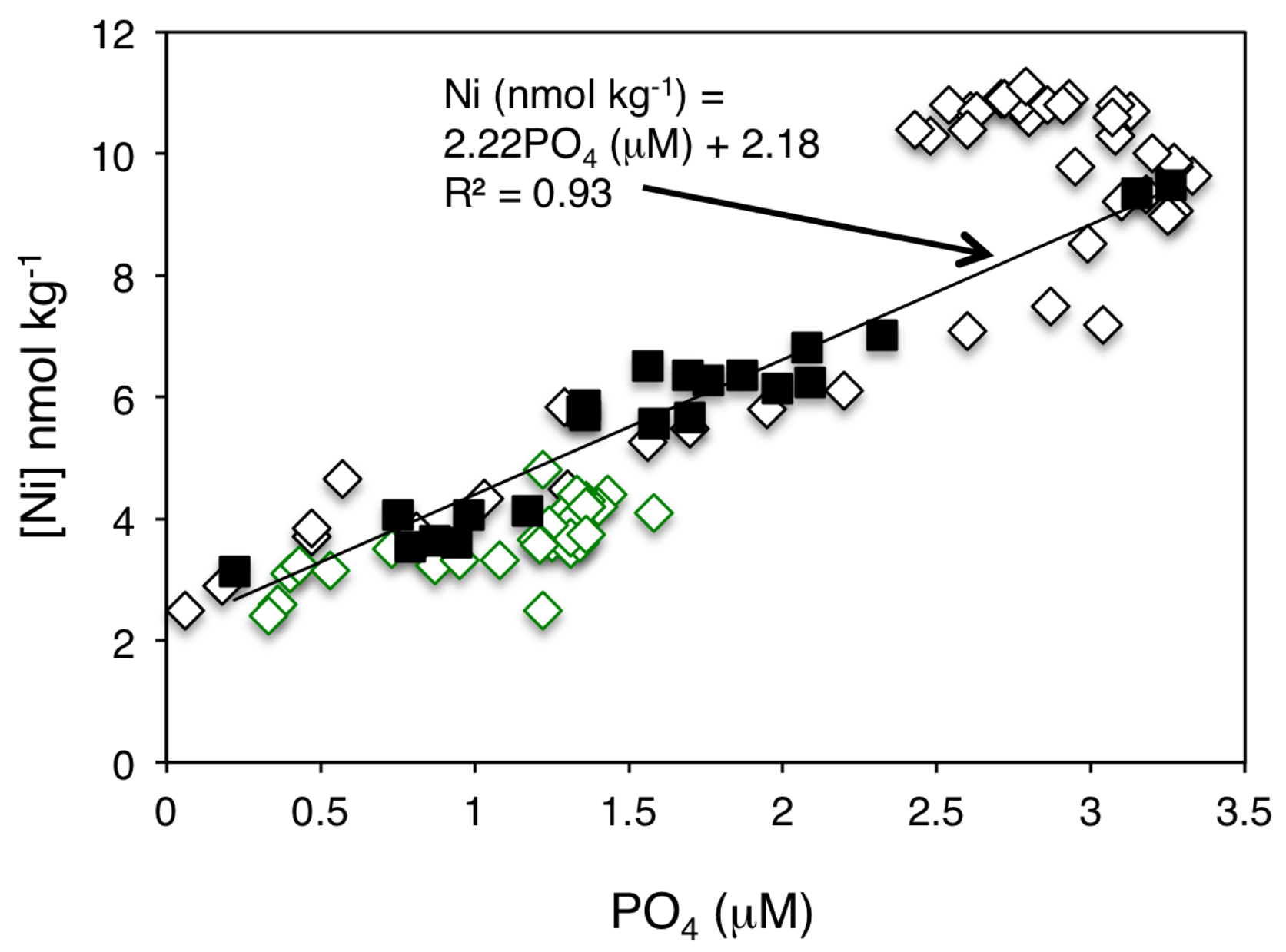


Cameron and Vance - Figure 8

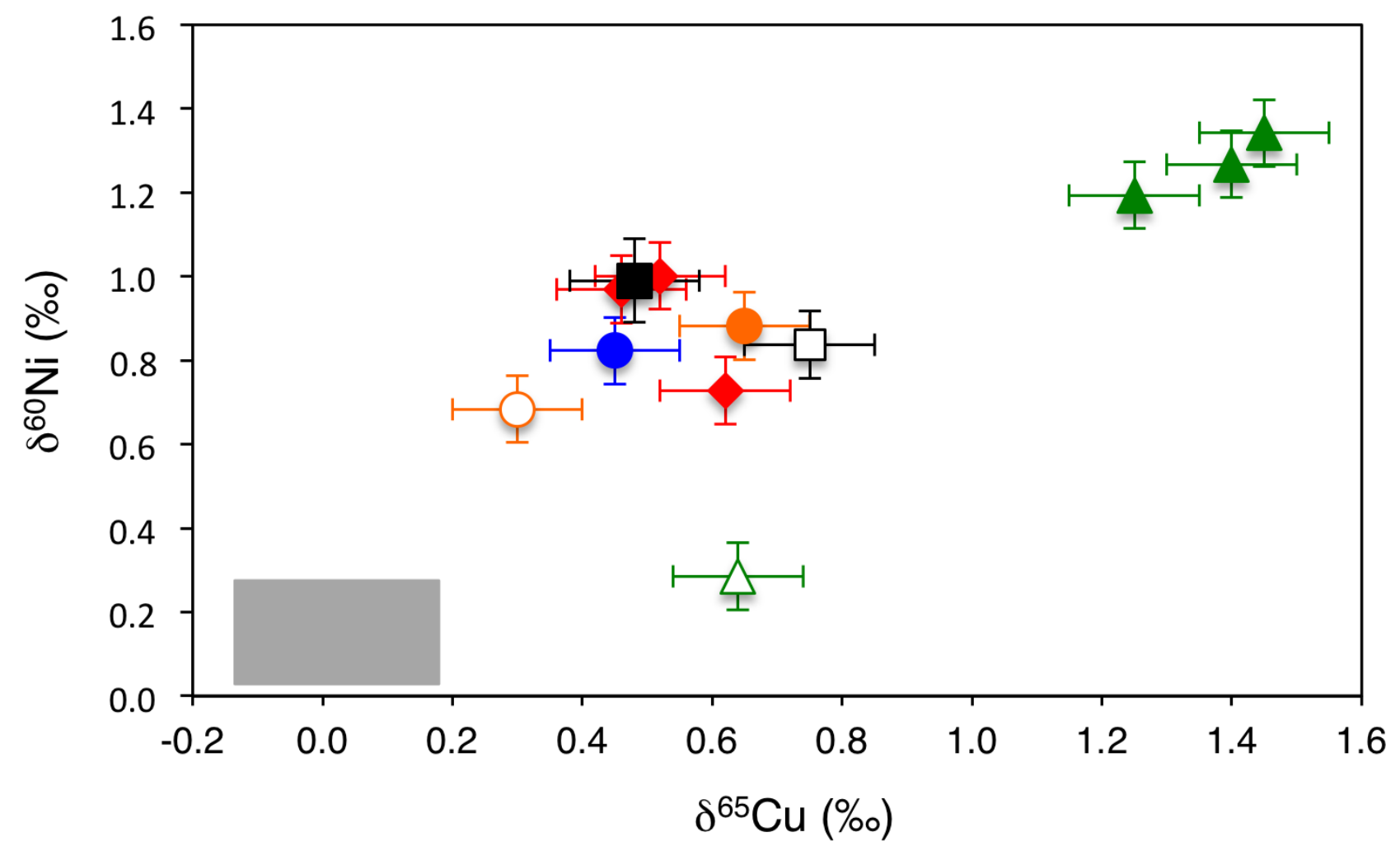


Cameron and Vance - Figure 9
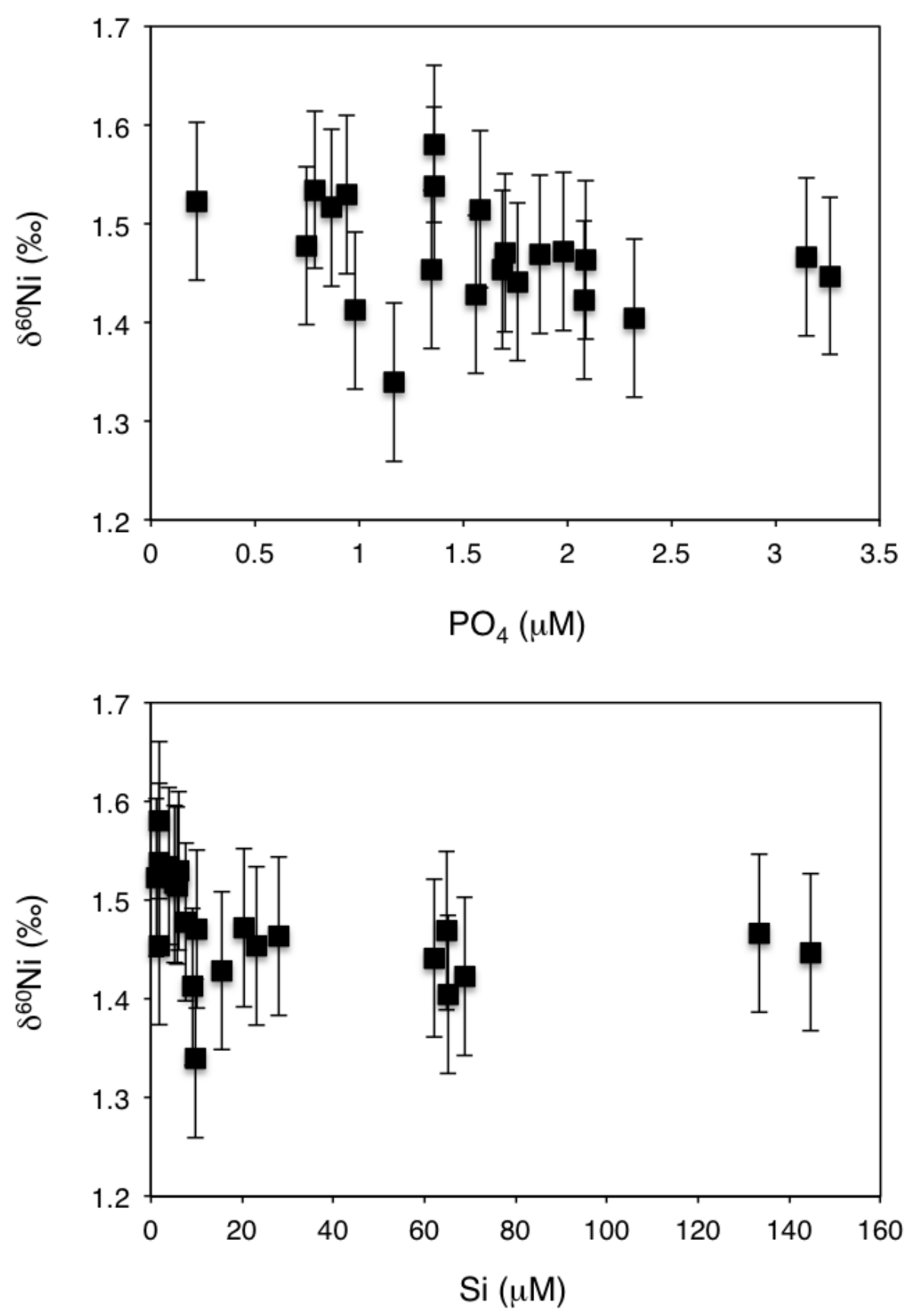